Document downloaded from:

http://hdl.handle.net/10251/145977

This paper must be cited as:

Silverio, N.; Barros, R.; Tiago Filho, GL.; Redón-Santafé, M.; Silva Dos Santos, IF.; De Mello Valerio, VE. (01-0). Use of floating PV plants for coordinated operation with hydropower plants: Case study of the hydroelectric plants of the Sao Francisco River basin. Energy Conversion and Management. 171:339-349.

https://doi.org/10.1016/j.enconman.2018.05.095

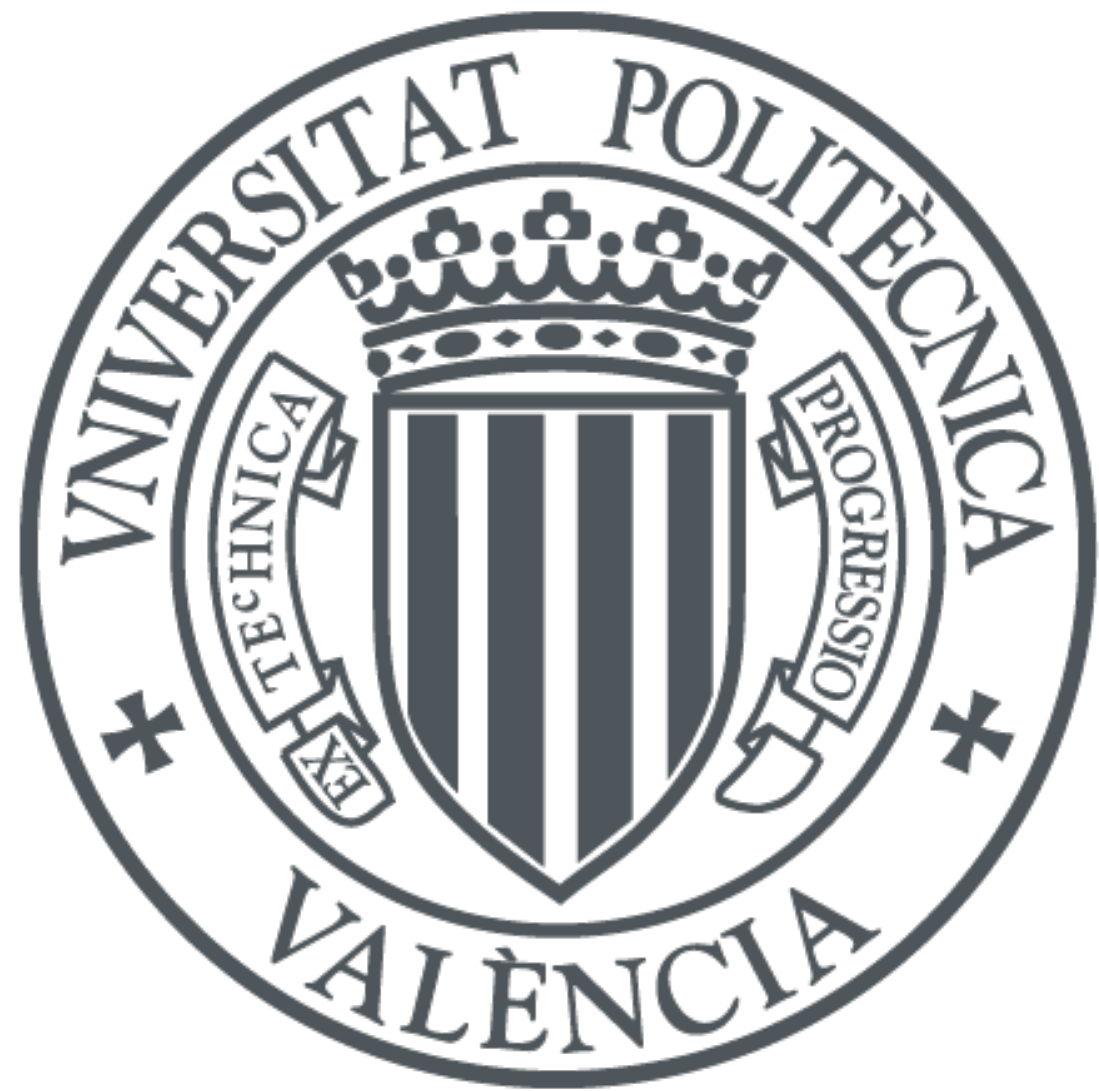

The final publication is available at

https://doi.org/10.1016/j.enconman.2018.05.095

Copyright Elsevier

Additional Information 


\title{
USE OF FLOATING PV PLANTS FOR COORDINATED OPERATION WITH HYDROPOWER PLANTS: CASE STUDY OF THE HYDROELECTRIC PLANTS OF THE SÃO FRANCISCO RIVER BASIN
}

\begin{abstract}
AUTHORS
Naidion Motta Silvério ${ }^{\mathrm{a}}$, Regina Mambeli Barros ${ }^{\mathrm{b}}$, Geraldo Lúcio Tiago Filho ${ }^{\mathrm{c}}$, Miguel Redón-Santaféd $^{\mathrm{d}}$ Ivan Felipe Silva dos Santos ${ }^{\mathrm{e}}$

${ }^{a}$ Master of Science in Engineering of Energy, Federal University of Itajubá, (Engenharia da Energia da Universidade Federal de Itajubá), Av. BPS, 1303, ItajubáMG, Phone: +55(35)36291224, Fax: +55(35)36291265, CEP: 37500-903, e-mail: naidionsilverio@hotmail.com
\end{abstract}

${ }^{\mathrm{b}}$ Professor of Natural Resources Institute, Federal University of Itajubá, National Reference Center in Small Hydropower, (Instituto de Recursos Naturais da

Universidade Federal de Itajubá, Centro Nacional de Referência em Pequenas Centrais Hidrelétricas), Av. BPS, 1303, Itajubá-MG, Phone: +55(35)36291224, Fax:

+55(35)36291265, CEP: 37500-903, e-mail: remambeli@ hotmail.com

${ }^{\mathrm{c}}$ Professor of Natural Resources Institute, Federal University of Itajubá, National Reference Center in Small Hydropower, (Instituto de Recursos Naturais da

Universidade Federal de Itajubá, Centro Nacional de Referência em Pequenas Centrais Hidrelétricas), Av. BPS, 1303, Itajubá-MG, Phone: +55(35)36291156, Fax: +55(35)36291265, CEP: 37500-903, e-mail: tiago_unifei@ hotmail.com

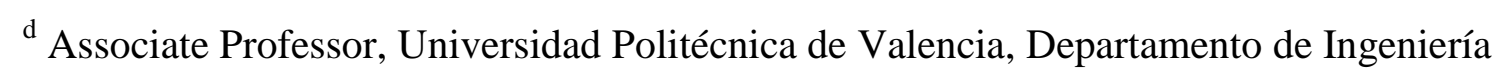
Rural y Agroalimentaria, Camino de Vera s/n, 46022 Valencia, Spain, e-mail: $\underline{\text { miresan@agf.upv.es }}$ 
${ }^{\mathrm{e}}$ Hydric Engineer. Student of Doctorate in Mechanical Engineering at UNIFEI, and Master of Science in Engineering of Energy, Federal University of Itajubá, (Engenharia da Energia da Universidade Federal de Itajubá), Av. BPS, 1303, Itajubá-MG, Phone: +55(35)36291224, Fax: +55(35)36291265, CEP: 37500-903, e-mail: ivanfelipedeice@hotmail.com

\section{ABSTRACT}

In recent years, the Brazilian electricity sector has seen a considerable reduction in hydroelectric production and an increase in dependence on the complementation of thermoelectric power plants to meet the energy demand. This issue has led to an increase in greenhouse gas emissions, which has intensified climate change and modified rainfall regimes in several regions of the country, as well as increased the cost of energy. The use of floating PV plants in coordinated operation with hydroelectric plants can establish a mutual compensation between these sources and replace a large portion of the energy that comes from thermal sources, thereby reducing the dependence on thermoelectric energy for hydropower complementation. Thus, this paper presents a procedure for technically and economically sizing floating PV plants for coordinated operation with hydroelectric plants. A case study focused on the hydroelectric plants of the São Francisco River basin, where there has been intense droughts and increased dependence on thermoelectric energy for hydropower complementation. The results of the optimized design show that a PV panel tilt of approximately $3^{\circ}$ can generate energy at the lowest cost (from $\mathrm{R} \$ 298.00 / \mathrm{MWh}$ to $\mathrm{R} \$ 312.00 / \mathrm{MWh}$, depending on the geographical location of the FLOATING PV platform on the reservoir). From an energy perspective, the average energy gain generated by the hydroelectric plant after adding the floating PV generation was $76 \%$, whereas the capacity factor increased by $17.3 \%$ on average. In terms of equivalent inflow, the PV source has a seasonal profile that 
compliments the natural inflow of the river. Overall, the proposed coordinated operation could replace much of the thermoelectric generation in Brazil.

Keywords: Hydro/PV coordinated operation; Hybrid PV hydroelectric power plant; Floating PV power plant; Solar hydroelectric power plant

\section{INTRODUCTION}

In Brazil, approximately $91 \%$ of the power generation is from hydropower plants $(64.3 \%)$ and thermal plants $(26.6 \%)$ [1]. The predominance of these two sources is due to the mode of operation of the Brazilian power and electrical system. Specifically, hydropower plants (with low emissions and costs) operate as a generation base [2]-[3], and thermal plants (with high emissions and costs) operate in a complementary state, thereby providing energy during the dry period and meeting the peak demand [4]. However, since 2012, the Annual Energy Balance [5] has exhibited a notable reduction in the contribution of hydroelectric plants and a gradual increase in the contribution of thermal power plants to the total energy supply. According to [6]-[7], low hydroelectric production can be linked to the recent climatic changes that have affected rainfall regimes in several regions of the country, mainly in the northeast. Prado et al. [8] noted that this trend is part of a vicious cycle of increased emissions, accelerated climate change, reduced hydropower production, increased dependence on thermal plants, and higher energy costs.

Thus, there is an evident need to investigate low-cost and clean energy sources that are capable of reducing the dependence on thermoelectric plants and complimenting hydropower. Among them, the use of solar energy could provide an important alternative from both an environmental perspective, due to low emissions [9], and a cost reduction perspective associated with future technological advancements [10]. However, the replacement of thermal power generation will require the construction of 
large centralized photovoltaic (PV) plants in the power system. This process can have adverse effects due to the typical fluctuations in the power output of these sources [11]. According to An et al. [12], the coordinated operation of a PV power plant and a hydroelectric plant (connected to the electric system through the same substation) can stabilize the PV output power and allow the introduction of the energy source at a large scale. Alternatively, the PV energy can supplement hydroelectric power generation in dry periods and can increase the ability to meet peak demands.

For hydro/PV coordinated operation to be possible, the PV power plant must be physically close to the hydropower plant so that both can be dispatched from the same substation [12] and that potential disturbances to frequency and speed regulators caused by the high variability in PV power generation in different geographical regions can be reduced [13]. This proximity requirement makes floating PV plants interesting options compared to land-based plants due to the possibility of occupying the large space that is available on the surface of the reservoir of the hydroelectric plant [14] rather than occupying surrounding areas that could be developed for other activities (recreation, tourism, etc.) [15] and that usually have unfavorable topography for the construction of large flat areas (on the order of $\mathrm{km}^{2}$ ) with PV panels.

This paper presents a procedure for technically and economically sizing floating PV plants for coordinated operation with hydroelectric plants. To consider the various losses associated with large photovoltaic systems, calculations were performed with the help of PVSyst ${ }^{\circledR}$ software. The case study focused on hydroelectric plants in the São Francisco River basin, the second most important basin in the country. This basin is mainly located in a region that is extremely vulnerable to intense droughts and that has experienced a corresponding increase in the dependence on thermoelectric energy to compliment hydropower production [16]. 
The paper is organized as follows. Section 2 presents a summary of the main projects using floating PV technology to demonstrate the technological variations and results of each project. Section 3 presents the simulation model used to calculate the energy output of floating PV plants and the methods used to determine the optimum tilt angle of the panels and to evaluate the energy benefits provided. Section 4 presents the results and discussion of tilt angle optimization, the levelized cost of energy (LCOE) value, and the energy gains associated with the coordinated operation proposed in this paper. Finally, section 5 presents the conclusions of the study.

\section{LITERATURE REVIEW}

\subsection{Floating PV projects}

Trapani and Santafé [17] presented a timeline with several floating solar energy generation systems that were installed from 2007 to 2013 around the world considering facilities with fixed panels and tracking systems. The photovoltaic panels covered the surfaces of enclosed water bodies (reservoirs and lakes) mainly used for irrigation purposes. In floating PV plants constructed in Spain and Italy (at latitudes of approximately $40^{\circ}$ ), the tilt angle of the panels reached as high as $10^{\circ}$. The main benefits presented by these projects included increasing the electricity output by up to $25 \%$ in Bubano, Italy, as a result of the cooling effect from the water and reducing evaporation from the reservoir. In this context, Choi [14], who compared the energy production of a floating PV plant with that of a nearby plant constructed on land for 7 months, reported an ideal slope of $11^{\circ}$, which results in an average production gain of $7.6 \%$ for floating panels. Sacramento et al. [18] performed a comparative analysis of a module on the ground and another in a water tank with an inclination of $0^{\circ}$ in a semi-arid region of Brazil. The results showed an average increase in efficiency of approximately $12.5 \%$ for the panel in the water tank. Ueda et al. [19] analyzed the production of a floating PV 
system compared to one installed on the margin of Aichi Lake in Japan over 5 years. They observed a reduction of $17 \%$ to $7.4 \%$ in the loss index due to the increase in temperature.

Sahu et al. [20] reviewed floating photovoltaic projects that were built prior to 2016 and added some new developments to a previously published project list [17]. Recently, two plants with capacities above $1 \mathrm{MWp}$ were installed on the Nishihira and Higashihira ponds in Kato City, Korea. The floating systems that were used were manufactured with high-density polyethylene (HDPE). The same technology was used in the Research and Development (R \& D) project subsidized by the San Francisco Hydroelectric Company (CHESF) in the Balbina and Sobradinho hydroelectric power plant reservoirs in Brazil. Each system had a potential output of $5 \mathrm{MWp}$. The energy generated by the floating PV systems complemented the produced hydroelectric energy. This approach takes advantage of two different energy sources using a single infrastructure that is already installed [21]. However, due to the recent construction of this project, the results have not yet been disclosed. Kim et al. [22] presented the PV floating projects developed in South Korea from 2009 to 2014. Between 2009 and 2010, the projects were for research purposes and, therefore, had small installed capacities. In 2011, some larger-scale PV floating projects were installed. The floating platforms of these projects had very similar designs, although the materials used in the construction of the structures varied and included steel fiber-reinforced polymer, polyethylene and plastic (FRP). 
146

147

148

149

150

151

152

153

154

155

156

157

158

159

160

161

162

163

164

165

166

167

\section{MATERIALS AND METHODS}

\subsection{Materials}

The case study focused on the hydroelectric plants in the São Francisco River basin. These plants are located between the southeast and northeast regions of Brazil along the $2,863 \mathrm{~km}$ that is occupied by the São Francisco River. Table 1 presents the main data from the hydroelectric plants that were analyzed.

Table 1. Main data from the hydroelectric plants that were analyzed

3

The PV panel that was used in the simulation was a generic $250 \mathrm{~W}_{\mathrm{p}}(60$ cells $)$ panel composed of polycrystalline silicon with dimensions of 1650 x $992 \mathrm{~mm}$. This panel and the associated information is listed in the PVSyst ${ }^{\circledR}$ database [23].

The costs used in the calculation of the LCOE are presented in Tables 2.

Table 2. Costs of a floating PV plant according to the tilt angle.

\subsection{Computational simulation parameters}

The PV energy calculation as a function of tilt angle, $E_{o}(\alpha)$, was performed in PVSyst ${ }^{\circledR}$. In this software, there is no option to simulate a floating PV plant, but the available parameters and the simulation of the desired conditions can be adjusted, as shown in the following subsections. The simulations were performed for a $1 \mathrm{MW}_{\mathrm{p}}$ plant to obtain a normalized energy $\left(\mathrm{MWh} / \mathrm{MW}_{\mathrm{p}}\right)$. This approach allows the estimation of the generation for any peak power. A power density $\left(\mathrm{kW}_{\mathrm{p}} / \mathrm{m}^{2}\right)$ is also obtained, which can be used to estimate the area required for installation based on any peak power. 


\subsubsection{Simulation model used in PVSyst}

The simulation model "Unlimited Sheds" was used to consider mutual shading losses among the rows of panels (Figure 1). This effect can be significant for utilityscale PV plants if the inter-row distance (pitch) is not correctly sized. The number of hours per day for which mutual shading can be avoided is controlled through the "shading limit angle". In addition, increasing the pitch affects the ground occupancy factor, thereby requiring a larger installation area for the same PV peak power.

Figure 1. Parameters of the Unlimited Sheds model available in PVSyst

\subsubsection{Albedo of water}

Albedo is a measure of the potential that a surface has to reflect the radiation from the sun. A model for estimating the albedo $(\rho)$ in different water bodies is presented in equation 1 [24]:

$$
\rho=c^{r \cdot \sin \gamma+1}
$$

where $c$ is the color coefficient, $r$ is the roughness coefficient (due to undulations), and $\gamma$ is the solar height.

Based on the coefficients presented in [24] for lakes and ponds with clear water and ripples of up to $2.5 \mathrm{~cm}(c=0.16 ; r=0.70)$, the albedo values for various sun heights can be obtained, as presented in Table 3.

Table 3. Albedo of the water as a function of solar height $\gamma$ 
Table 3 presents the values of albedo with an average and standard deviation equal to $0.096 \pm 0.025$. Thus, the albedo used for the simulation in PVSyst ${ }^{\circledR}$ was the average value of $\rho=0.096$. This value is well below the default value (for the ground) of $\rho=0.020$.

\subsubsection{Natural wind cooling}

The literature review did not yield a method for determining the natural wind cooling effect on PV panels that are installed on floating platforms. As such, based on wind flow obstruction at the back of the modules caused by the shape of the floating platforms, as shown in Figure 2, the thermal behavior of PV modules was defined in PVSyst ${ }^{\circledR}$ as "Integration with fully insulated back", i.e., without natural cooling at the back.

\subsubsection{Figure 2. Shape of floating platforms a) Isifloating ${ }^{\circledR}$ and $b$ )}

$$
\text { Hydrelio }{ }^{\circledR} \text { increased-efficiency PV panels }
$$

The peak power $\left(\mathrm{W}_{\mathrm{p}}\right)$ of the PV panel is established under standard test conditions (STC: irradiation of $1000 \mathrm{~W} / \mathrm{m}^{2}$, air mass of 1.5 and cell temperature $25^{\circ} \mathrm{C}$ ) [25]. This value decreases by $0.5 \%$ per ${ }^{\circ} \mathrm{C}$ of cell temperature increase in the STC value on average [26]. For modules operating on the ground, [18] and [27] reported temperatures of $42.8^{\circ} \mathrm{C}$ and $65.1^{\circ} \mathrm{C}$, respectively. With the objective of absorbing the heat surplus that is generated by the PV panel, Bahaidarah et al. [27] used a stream of water on the back of a PV panel and obtained a 34\% reduction in temperature. Therefore, because the PV modules that are installed on floating platforms have natural water flows below their back surfaces, they operate at lower temperatures and with higher efficiencies than modules installed on land. 
Therefore, an analysis of the results presented in [14], [18], and [19] allows us to conclude that differences in climate and the tilt of PV modules are the most important variables that increase the efficiency of PV panels installed on floating platforms. Therefore, a conservative value of $7 \%$ was considered the efficiency improvement for PV panels at Brazilian hydroelectric power plants. This value is used to estimate the normalized power $\left(\mathrm{E}_{\mathrm{norm}}\right)$ generated by the floating PV plants.

\subsection{Evaluation of the influence of the tilt angle on the energy cost}

For the same peak power, a higher PV panel tilt demands greater spacing between storage, transport, field construction time, and anchorage systems (presented in Table 2). In contrast, depending on the location, larger tilts can maximize the energy that is collected by PV panels. Therefore, it must be determined whether the energy benefit offsets the additional costs.

LCOE analysis can indicate the tilt at which energy will be generated at the lowest price. Darling et al. [28] presented a simplified LCOE equation for utility-scale PV plants. To evaluate the best tilt option ( $\alpha$ ) for a floating PV design, the influence of $\alpha$ on the variables that are presented in the original equation must be considered. Then, the minimum value of the LCOE $(\alpha)$ function must be obtained according to equation 2:

$$
\min \operatorname{LCOE}(\alpha)=\frac{C_{i}(\alpha)+\sum_{n=1}^{N} \frac{A O(\alpha)}{(1+D R)^{n}}-\frac{R V(\alpha)}{(1+D R)^{n}}}{\sum_{n=1}^{N} \frac{E_{o}(\alpha) \times(1-S D R)^{n}}{(1+D R)^{n}}}
$$


235 the residual value as a function of $\alpha$, considered $10 \%$ of the investment value; $\mathrm{E}_{\mathrm{o}}(\alpha)$ is

236 the energy produced in year zero as a function of $\alpha$; SDR is the degradation rate of the

237 PV system, considered $0.6 \%$ per year; $\mathrm{N}$ is the number of exploitation years, considered

238

239

25 years; and DR is the discount rate, considered $10 \%$.

To calculate the energy produced $\left(\mathrm{E}_{\mathrm{o}}\right)$, losses due to mutual shading should be considered. These losses can only be avoided if the rows are very far apart, thereby making the cost of the floating system unreasonable [29]. Therefore, it is necessary to establish a period of the day in which the plant will be free of mutual shadows and ensure that it is not exceeded in when calculating the energy generated at different tilts $(\alpha)$

\subsection{Tilt angle restrictions (dust and wind actions)}

\subsubsection{Minimal tilt to avoid soiling losses}

The analysis of soiling losses on the surface of PV modules is an important stage in the determination of $\alpha$ due to its negative influence on the absorption of solar radiation [30]. In this context, Hegazy [31] investigated the accumulation of dust on glass plates with different tilt angles and the associated influence on the solar transmittance of the material for one year. The results showed that the reduction in the normal transmittance of the glass strongly depended on the tilt of the plates and the local climatic conditions.

However, no studies were found in the literature related to the accumulation of dust on PV panels installed on reservoirs in Brazil. The default value of $3 \%$ was adopted in PVSyst ${ }^{\circledR}$ software annual soiling losses. According to the PVSyst ${ }^{\circledR}$ manual, this value provides a good estimation for minimum inclination angles between $2^{\circ}$ and $3^{\circ}$ $[32]$. 


\subsubsection{Maximum tilt for limiting wind loads}

It is of utmost importance to evaluate the adverse effects of the tilt angle of PV panels and the intensity of forces caused by the wind on the floating platform and anchoring system. [33]. However, current standards related to wind forces on structures are not adequate and do not provide aerodynamic or pressure coefficients to evaluate the forces associated with PV installations [34]. In practice, coefficients of the structures that are similar to those for PV panels on platforms [33] or roofs [11] have been adopted.

From the Brazilian standard for calculating wind loads, NBR 6123 [35], a methodology for calculating the resulting forces on various structural elements and characteristic wind speeds in Brazilian regions can be obtained. The elements closest to a floating PV structure are considered as "flat water insulated cover", and the cover represents the PV module that is open at the sides and back, as in the model shown in [36]. Additionally, a "1-sided roof in rectangular plant buildings" is considered. In this case, the roof represents a PV module that is totally or partially closed according to the models of the manufacturers Ciel et Terre [37] and Isifloating [38]. The maximum load that the system can withstand provides the technical constraint for the maximum value of $\alpha$.

\subsection{Limitation of PV peak power for $\mathrm{Hydro} / \mathrm{PV}$ coordinated operation}

The poor electrical quality of PV energy, which is a consequence of the randomness and intermittency of the solar resource, makes the integration of utility-scale PV plants into power systems difficult because it imposes risks to the operative stability of the system and creates associated high investments in spinning reserves [39]. Moreover, in interconnected systems, when the local market does not consume all the power that is generated, it is transmitted to remote markets that can be thousands of miles away. 
284 Therefore, a stable power source is essential for avoiding substantial changes in power

285 flow and voltage fluctuations. Therefore, for large-scale PV generation, it is extremely

286 important to improve power quality [12].

287 Due to their operational flexibility, hydroelectric plants have considerable potential 288 for offsetting PV instability in real time [12], [39]. Thus, according to An et al. [12], the 289 principles of hydro/PV coordinated operation can be stated as follows.

290 - In short-term scheduling, hydropower can compensate for the variability of PV

291

292

293

Figure 3. PV compensation through hydropower: the elimination of (a) the randomness and (b) the intermittency is verified

Source: [12]

To ensure that hydropower is capable of compensating for the power deficiency created by a steep decline in PV output, in the most important PV generation scenario, it is necessary to establish restrictions on the size of the PV plant. Fang et al. [39] conservatively established the installed capacity of a hydroelectric plant as the maximum limit of PV peak power to be installed according to equation 3. Economic factors are also evaluated for optimum PV plant design in [39].

$$
0 \leq N_{i n}^{P V} \leq N_{i n}^{H}
$$


hydroelectric plant.

\subsection{Modeling of PV energy as an equivalent inflow to the hybrid plant}

Because the PV power generated to complement the hydroelectric power prevents a certain volume of water from being consumed and is stored in the reservoir for use during peak periods, the model presented in [40] can be used to convert PV energy into an equivalent inflow that reaches the reservoir during the analysis period. In [40], the equivalent inflow is obtained by pumping water from a lower reservoir into an upper reservoir through a process that uses energy from a PV plant that is built on the ground and near a reversible hydroelectric plant. This approach can be used in this study by considering the pumping stage ideal; that is, all PV energy is converted into an equivalent inflow. Equation 4 presents this relationship:

$$
V_{E Q(i)}=\frac{E_{e l P V(i)}}{d \cdot g \cdot H_{T E(i)}}
$$

where $V_{E Q(i)}$ is the equivalent flow corresponding to the PV power generated in period $i, E_{e l P V(i)}$ is the total energy generated by the floating PV plant in period $i, d$ is the density of water $\left(1000 \mathrm{~kg} / \mathrm{m}^{3}\right), g$ is the gravitational constant $\left(9.81 \mathrm{~m} / \mathrm{s}^{2}\right)$, and $H_{T E(i)}$ is the hydraulic head in period $i(\mathrm{~m})$. The period $i$ could represent hours, days, weeks, etc.

\subsection{PV internal lines connecting solar power to a hydroelectric} substation

For floating PV plants with installed power on the order of hundreds of megawatts, it is necessary to divide the PV array into sub-PV arrays to make the transmission of 
330 large blocks of energy through an internal line technically possible. The costs of these

331 networks in the LCOE must be considered because the PV array may have to be built

332 away from the hydroelectric substation due to environmental and water use issues.

333 Thus, based on the limitations of low-voltage energy transmission [41], Figure 4 334 displays the basic scheme of internal lines used to quantify the effects of the line length 335 (i.e., cost) on the LCOE.

Figure 4. Basic scheme of internal lines for a floating PV power plant in a hydroelectric reservoir

\section{RESULTS AND DISCUSSION}

341

\subsection{Simulation results}

The simulation parameters defined in section 3.1 were used in simulations executed with PVSyst ${ }^{\circledR}$ for a floating PV power plant in the Três Marias hydroelectric reservoir for different tilt angles $(\alpha)$, and the results are presented in Table 4.

Table 4. Summary of the simulations for different topologies of the hydroelectric Três

$$
\text { Marias Power Plant }
$$

The maximum shading limit angle $(\theta)$ that ensures the floating PV plant at Três Marias will not suffer losses caused by mutual shading in a period of $8 \mathrm{~h}$ to $16 \mathrm{~h}$ is $\theta=32^{\circ}$. The value of $\theta$ is controlled by the spacing between the rows of panels, which is called pitch $(\mathrm{P})$. The value of $\mathrm{P}$ is based on the greater value between the distance that ensures there are no losses due to mutual shading $\left(\mathrm{P}_{\text {sha }}\right)$ and the minimum distance 
352 required for performing plant maintenance $\left(\mathrm{P}_{\mathrm{man}}\right)$. Normally, for higher tilts, the value

353 of $\mathrm{P}_{\text {sha }}$ is greater than $\mathrm{P}_{\operatorname{man}}$ because, under these conditions, more space between rows is 354 necessary to avoid mutual shading. However, as $\alpha$ decreases, the rows may be 355 approximated because the shadows that are cast by the panels are small. Thus, $\mathrm{P}_{\text {sha }}$ 356 approaches $P_{\operatorname{man}}$ as $\alpha$ decreases, which, in this geographical location, occurs at $\alpha=15^{\circ}$.

357 At this point, $\mathrm{P}_{\text {sha }}$ must be equal to $\mathrm{P}_{\operatorname{man}}$, even though $\mathrm{P}_{\text {sha }}$ represents a smaller spacing between rows, because a minimum space of $0.50 \mathrm{~m}$ is required for maintenance. This distance should be added to the horizontal projection of the panel to obtain $\mathrm{P}_{\operatorname{man}}$. of the total area of the PV modules to the total area occupied by the PV power plant; the latter also considers the spacing $\mathrm{P}$ between rows. Therefore, because the total area of the PV modules used in this study for $1 \mathrm{MW}_{\mathrm{p}}$ is always $6508 \mathrm{~m}^{2}$, the area occupied by each $\mathrm{MW}_{\mathrm{p}}$ of the floating PV plant $\left(\mathrm{A}_{\mathrm{flo}}\right)$ can be determined. The power density is obtained by taking the inverse of $\mathrm{A}_{\text {flo }}$ and can be used to estimate the area occupied to achieve any PV peak power. The normalized energy $\left(\mathrm{E}_{\text {norm }}\right)$ is the result of simulating $1 \mathrm{MW}_{\mathrm{p}}$ of generation in PVSyst ${ }^{\circledR}$. This value can be used to estimate the energy generated by any installed system with a given peak power at this location. The same procedure was performed for other hydropower plants, but the results are only demonstrated based on the LCOE and $\mathrm{E}_{\text {norm}}$.

\subsection{Optimizing the PV panel tilt angle}

\subsubsection{Evaluation of influence of the tilt angle on the LCOE}

The energy results from the previous section are related to costs of the floating PV system for determining the $\operatorname{LCOE}(\alpha)$, as shown in the graphic in Figure 5. 
Although the analyzed hydroelectric plants are in distinct geographic regions

379

380

381

382

383

384

385

386

387

with latitudes ranging from $9^{\circ}$ to $19^{\circ}$ south, similar LCOE $(\alpha)$ behavior is observed, with a minimum value (below $\mathrm{R} \$ 290 / \mathrm{MWh}$ ) at $\alpha=0^{\circ}$ that increases as $\alpha$ becomes larger. From this perspective, $\alpha$ should be less than $5^{\circ}$. However, an analysis based only on energy maximization, as presented in [29], would lead to very different results and target values of $\alpha \approx 15^{\circ}$ as the best option. However, this would imply values above $\mathrm{R} \$ 338 / \mathrm{MWh}$. Thus, the importance of considering economic factors in the design of floating PV plants is clear because the energy gain obtained by increasing $\alpha$ may not justify the increase in the cost of the system. The LCOE graphic can also be used to identify the hydropower plants in the basin where the construction of a floating PV plant is more financially viable, such as the Três Marias, Retiro Baixo, and Queimado plants in this case. These plants can be selected to stimulate the development of the sector with later expansion to other plants throughout the country.

There is one gap among the LCOE curves that visibly separates them into two groups. This separation is due to the considerable geographic distance between these groups. Specifically, the São Francisco River basin creates different climatic zones. The plants that receive more solar radiation (Três Marias, Retiro Baixo, and Queimado) exhibit small LCOEs for any $\alpha$. Reviewing the geographical data in Table 1, it is apparent that neighboring hydroelectric plants exhibit very similar LCOE values.

\subsubsection{Tilt angle restrictions due to soiling losses}

Restricting the minimum value of $\alpha$ is based on the accumulation of dirt, as presented in subsection 3.3.1. Thus, equation 5 represents this restriction condition.

$$
\alpha \geq 3^{\circ}
$$




\subsubsection{Tilt angle restrictions due to wind loads}

The restriction to the maximum value of $\alpha$ is based on the maximum load the anchorage system can withstand and the resistance of the floating elements. In accordance with the methodology presented in subsection 3.3.2, the most severe situation occurs when the incidence angle of the wind is $+45^{\circ}$. In these conditions, the horizontal forces on each floating platform as a function of $\alpha$ are presented in Figure 6 for PV panels with dimensions presented in section 3.

\section{Figure 6. Horizontal force caused by the wind load on a PV panel as a function of $\alpha$}

The maximum limit for the horizontal force $(100 \mathrm{kN})$ defined in [33] was based on the limitation of the anchoring system considering that it would be technically and economically infeasible to build ground foundations that are capable of withstanding larger forces. In floating PV plants with many rows, there is a reduction in the horizontal forces caused by the wind-break effect that the windward rows exert on the adjacent leeward rows. The coefficient of reduction Fs $=0.75$ used in [33] was also considered for the construction of Figure 7.

\section{Figure 7. Horizontal force based on the width of the floating platform}

Figure 7 shows that the larger the value of $\alpha$ is, the shorter the distance at which the maximum force of $100 \mathrm{kN}$ will be reached, i.e., a smaller number of PV panel rows. Thus, the maximum possible length is approximately $2400 \mathrm{~m}$, which can only be reached for a tilt angle of up to $3^{\circ}$. Because the floating PV plants in this study have a peak power on the order of hundreds of $\mathrm{MW}_{\mathrm{p}}$, the initial minimum length of the floating 
426 platform will be approximately $1000 \mathrm{~m}$. This length is only valid for tilt less than $8^{\circ}$

427 (dotted green line). Equation 6 presents the initial condition for the maximum tilt

428

429

430

431

432

433

434

435

436

437

438

439

440

441

442

443

444

445

446

447

448 restriction.

$$
\alpha \leq 8^{\circ}
$$

Limiting the maximum value of $\alpha$ to $8^{\circ}$ is in accordance with the tilt angles of the panels used in designs developed and presented in reference [14], in which the maximum angle was $10^{\circ}$. Thus, it is evident that even at latitudes higher than those of the hydroelectric basin of the São Francisco River in Brazil (e.g., in Spain and Italy), the tilt angle should not exceed $10^{\circ}$ to limit the effects of wind, although in these tilts the energy collected by the PV panels is not the maximum.

\subsubsection{Determination of the optimum tilt angle}

To determine the optimum $\alpha$, one should simultaneously consider the conditions presented in the three previous subsections. Equations 5 and 6 establish the upper and lower technical limits for $\alpha$ that are summarized in equation 7.

$$
3^{\circ} \leq \alpha \leq 8^{\circ}
$$

\section{3}

An analysis of the LCOE $(\alpha)$ graphic (Figure 5) indicates that floating PV plants yield the lowest cost at tilts less than $5^{\circ}$. Based on this finding, the optimum tilt angle is defined as $\alpha=3^{\circ}$. This $\alpha$ value is much smaller than those (ranging from $8^{\circ}$ to $11^{\circ}$ ) used in other projects discussed in the literature review, and this difference is related to the sizing method. Previous studies based their values on maximizing the energy collected 
by the PV array (obviously limited by wind load) but did not consider the influence of increasing the angle on the cost of the floating PV system. In addition, such projects used floats with very different characteristics than those used in this study (Figure 2).

\subsection{Coordinated Hydro/PV operation}

\subsubsection{Determination of maximum power for coordinated Hydro/PV} operation

As presented in section 3.4, the PV peak power must be limited to the value of the installed capacity of the hydropower plant. The area occupied for peak power (using the power density) and the percentage of the surface area of the reservoir occupied by each hydroelectric power plant can be determined from the optimum tilt $\alpha=3^{\circ}$, as shown in Table 5.

Table 5. Peak powers and occupied areas of floating PV plants

(1)

The analysis includes two types of hydropower facilities: those with storage reservoirs and run-of-the-river plants. In the case of storage reservoir facilities, the floating PV plant occupies a maximum reservoir surface area of 3.58\%, which in principle does not compromise other activities (tourism, fish farming, etc.).

However, in the case of run-of-the-river facilities, the percentage of the surface occupied can reach $48.31 \%$, which can cause serious conflicts with other activities. In addition, in the case of the Paulo Afonso I, II, III and IV hydroelectric plants, the areas occupied by the floating PV plant would be much larger than the surface areas of the available lakes (surpassing 100\% occupancy). This is a very unique case because the Paulo Afonso complex comprises 4 hydroelectric power plants (Paulo Afonso I, II, III and IV), which have 2 small impoundments and a very high installed power (3880 MW). Thus, since it is not possible to construct floating PV plants with peak power 
473

474

475

476

477

equal to the installed capacity of the respective hydroelectric dams in the available area on the surface of the Paulo Afonso I, II, III and IV reservoirs, as described in section 3.4, these cases were excluded from the energy analysis. The floating PV plant of the Apolônio Sales hydroelectric plant was also excluded from the energy analysis due to the lack of generation data, even though the area of the reservoir occupied by the floating PV plant is acceptable. The best reservoir location for constructing a PV arrangement depends on several environmental, economic, and technical factors, for which detailed information and studies of the reservoirs and their margins are necessary. These factors that will not be addressed in this study.

\subsubsection{Expected floating PV generation}

In terms of the designed tilt angle and peak power of each PV plant, annual and monthly PV generation can be estimated using the normalized energy $\left(\mathrm{E}_{\mathrm{norm}}\right)$ calculated for each PV plant in the corresponding time interval. The bars in Figure 8 show the average energy generated by the hydroelectric plants over the past 3 years according to the data available in [42]-[44], as well as the annual PV energy obtained from the computational simulation. In addition, the points on the curves show the capacity factors (CFs) of the hydroelectric plants without the contribution of the PV floating source (yellow curve) and with the contribution of the PV floating source (blue curve). (1)

Figure 8 . Annual energy generated by the hydroelectric plants and floating PV plants 
Figure 8 shows a significant increase in PV energy production, which represents

$51.0 \%$ of the average energy generated by the Xingó hydroelectric plant and exceeds the average power generated at the Retiro Baixo hydropower plant $(105.6 \%)$, in which the hydroelectric generation CF $(16.7 \%)$ is worse than that of the PV plant installed at the same location. Três Marias and Sobradinho also exhibited low CFs (near 20\%) in the past 3 years, in these cases, the PV generation would represent a greater than $85 \%$ increase in energy generated and a CF upgrade of approximately $15 \%$. The average annual energy gain produced by the proposed coordinated operation for the hydroelectric plants in the São Francisco River basin would be approximately $76 \%$, and the average $\mathrm{CF}$ increase for the hybrid plants would be approximately $17.3 \%$ in relation to that of the original hydroelectric power plant without the contribution of PV energy.

\subsubsection{Equivalent inflow for a floating PV plant}

According to section 3.5, PV energy can be converted into an equivalent inflow that reaches the reservoir and can be added to the natural inflow of the river, resulting in a total water inflow available in the analyzed period. Thus, the existing Brazilian optimization models can be used to program the dispatch of the hybrid plant formed by the hydroelectric and floating PV plants operating in a coordinated and complementary manner. Figure 9 shows the inflows: the natural inflow of the river (in blue) and the equivalent PV (in red) and total (in green) flows for each hydroelectric plant in the São Francisco River basin.

The increase in the equivalent inflow is very similar to the increase in PV energy presented in Figure 8 and is more representative of hydroelectric plants with low CFs. In these cases, the equivalent inflow created by the PV energy exceeds the natural inflow during the dry period, which in the southeastern and northeastern regions of Brazil is between May and November. As shown in equation 4, the equivalent inflow 
522 can be obtained for any time interval $i$. Since dispatch scheduling is usually done per

523 operative week, it is sufficient to obtain the normalized PV energy and hydraulic head 524 available per week to calculate the weekly equivalent inflows.

525 Under the current regulatory perspective of the Brazilian electricity market, it is 526 only appropriate to add the equivalent inflow from the PV source to the natural flow of 527 the river if the prices of both power sources are the same. However, the sale price of 528 hydroelectric energy registered at the last auction was $\mathrm{R} \$ 166.92 / \mathrm{MWh}$ [45], which 529 makes it impossible to consider the flow rates together. However, since the objective of 530 this work is to perform an energy analysis for a future scenario in which it is estimated 531 that the sale price of PV energy will be close to that of hydroelectric energy, regulatory 532 issues are not addressed.

534 Figure 9. Natural, equivalent and total inflows for each hydroelectric plant in the São 
536

537

538

539

540

541

542

543

544

545

546

547

548

549

550

551

552

553

554

555

556

557

558

559

560

\subsection{Impact of internal lines on the LCOE}

To technically enable the transmission of the energy generated by low-voltage PV panels to the hydroelectric substation, it is necessary to increase the voltage to standardized high-voltage levels $(13.8 \mathrm{kV}, 34.5 \mathrm{kV}, 69 \mathrm{kV}$, etc.) and to build internal lines aboveground or underground to transmit energy. The cost of these transmission systems is a linear function of the length of the internal lines; therefore, the greater the distance the floating PV plant is built from the hydroelectric substation, the greater the cost is. Figure 10 presents the variation in the LCOE as a function of the length of the underground 13.8-kV collection network that transmit the energy from the 4.7 MVA subarray, as shown in Figure 3. The internal lines could be configured with higher voltages or by constructing a substation for which the energy from all the subarrays would be input and few high-voltage lines (preferably compatible with the voltage level of the hydroelectric substation: $138 \mathrm{kV}, 230 \mathrm{kV}$, etc.) would transmit the output. The criterion for choosing the best configuration is economic based and is not presented in this study.

Figure 10. Variation of the LCOE as a function of the length of internal lines

\section{CONCLUSIONS}

Recent climate changes and intense drought have contributed to a decrease in hydroelectric production and an increase in the dependence on thermoelectric power plants to meet energy needs, especially in the northeast region of Brazil. In this sense, this study presents an alternative to complement the hydroelectric plants through coordinated operation with utility-scale PV floating plants. The addition of large PV plants to compensate for hydroelectric plants could reduce the variability and 
561 intermittency of the PV energy source and improve the energy quality, which is one of

562 the greatest obstacles of large-scale applications in power systems. Additionally, the PV 563 plant can complement the hydroelectric plant during drought periods (when clouds are

564 less common). Furthermore, this approach increase the capacity of the hydroelectric 565 plant to meet peak demands of the system because during daylight hours, the PV energy 566 prevents a certain volume of water from being consumed, and this volume can be used 567 for generation during the peak period.

568 For hydro/PV coordinated operation, the two plants must be connected to the 569 electrical system through the same substation. Thus, the PV plant must be built close to 570 the hydroelectric plant. Because of this issue, floating PV plants on the surface of the 571 plant reservoir, rather than located in nearby areas that generally have unfavorable 572 topography for the construction of PV plants, are ideal. Cost is another limiting factor 573 for the use of PV sources; therefore, a technical and economic analysis of the various 574 design variables of a floating PV system was presented. Among these variables, tilt has 575 one of the greatest influences on the LCOE due to increases in the costs of the floating 576 system that are directly proportional to the tilt angle. Thus, the choice of tilt based only 577 on the technical criterion of energy maximization can lead to LCOE values that make 578 this technology unfeasible. The distance from the floating PV plant to the hydroelectric 579 substation is another factor to consider in the design stage because it can make the cost 580 of energy unfeasible. LCOE costs for an internal line of up to $20 \mathrm{~km}$ (ranging from $581 \mathrm{R} \$ 320 / \mathrm{MWh}$ to $\mathrm{R} \$ 342 / \mathrm{MWh}$ ) are competitive when compared to some thermal plants that have been dispatched in recent years in the Brazilian power system. The results of the simulations in PVSyst ${ }^{\circledR}$ for floating PV plants suggest a significant increase in energy output, varying from $51.2 \%$ to $105.6 \%$, for the hybrid power plants (formed by the hydroelectric and floating PV plants). To incorporate the 
586

587

588

589

590

591

592

593

594

595

596

597

598

599

600

601

602

603

604

605

606

607

608

609

610

energy results into the existing optimization algorithms of the electric system, a method is presented to model the PV energy as an equivalent inflow that can be added to the natural flow of the river to obtain the total inflow reaching the hybrid plant. An analysis of the monthly profiles of these flows revealed the ability of the floating PV plant to complement the hydropower plant in the dry period, in which the equivalent inflow exceeded the natural inflow of the river. This approach represents a valuable possibility to store more water for the hydroelectric plant and, consequently, to reduce the dependence on thermal complementation to meet power system demands.

\section{ACKNOWLEDGEMENTS}

The authors would like to thank the Brazilian National Council for Scientific and Technological Development (Conselho Nacional de Desenvolvimento Científico e Tecnológico, $\mathrm{CNPq}$; in Portuguese) for granting a productivity in research scholarship to Prof. Regina Mambeli Barros (PQ2, Process number: 301986/2015-0) and Prof.

Geraldo Lúcio Tiago Filho and to the Brazilian Coordination for the Improvement of Higher Education Personnel (Coordenação de Aperfeiçoamento de Pessoal de Nível Superior, Capes; in Portuguese) for granting the Master of Science scholarship to Naidion Motta Silvério and the Doctorate scholarship to Ivan Felipe da Silva dos Santos.

\section{BIBLIOGRAPHY}

[1] A. N. de E. Elétrica, "BIG- Banco de informações de geração.” [Online]. Available: http://www2.aneel.gov.br/aplicacoes/capacidadebrasil/capacidadebrasil.cfm. [Accessed: 22-Nov-2017]. 
611 [2] V. Freitas, A. Olímipio, P. Junior, J. D. Hunt, and M. Aur, "Enhanced-Pumped-

612

613

614

615

616

617

618

619

620

621

622

623

624

625

626

627

628

629

630

631

632

633

634

635 Storage : Combining pumped-storage in a yearly storage cycle with dams in cascade in Brazil," Energy, vol. 78, pp. 513-523, 2014.

[3] R. C. Zambon et al., "Optimization of Large-Scale Hydrothermal System Operation,” J. water Resour. Plan. Manag., vol. 138, pp. 135-143, 2012.

[4] R. Bruno et al., "Maximizing hydro share in peak demand of power systems long-term operation planning," Electr. Power Syst. Res., vol. 141, pp. 264-271, 2016.

[5] Empresa de Pesquisas Energéticas, “Balanço energético nacional 2016,” 2016. [Online]. Available:

https://ben.epe.gov.br/downloads/Relatorio_Final_BEN_2016.pdf. [Accessed: 22-Nov-2017].

[6] J. L. D. S. Soito and M. A. V. Freitas, “Amazon and the expansion of hydropower in Brazil: Vulnerability, impacts and possibilities for adaptation to global climate change," Renew. Sustain. Energy Rev., vol. 15, no. 6, pp. 3165 $3177,2011$.

[7] A. F. P. de Lucena et al., "The vulnerability of renewable energy to climate change in Brazil," Energy Policy, vol. 37, no. 3, pp. 879-889, 2009.

[8] F. A. Prado, S. Athayde, J. Mossa, S. Bohlman, F. Leite, and A. Oliver-Smith, "How much is enough? An integrated examination of energy security, economic growth and climate change related to hydropower expansion in Brazil," Renew. Sustain. Energy Rev., vol. 53, pp. 1132-1136, 2016.

[9] J. L. Silveira, C. E. Tuna, and W. D. Q. Lamas, "The need of subsidy for the implementation of photovoltaic solar energy as supporting of decentralized electrical power generation in Brazil," Renew. Sustain. Energy Rev., vol. 20, pp. 

133-141, 2013.

[10] A. Energiewende, "Current and Future Cost of Photovoltaics Current and Future Cost of Photovoltaics,” 2015. [Online]. Available: https://www.ise.fraunhofer.de/content/dam/ise/de/documents/publications/studies /AgoraEnergiewende_Current_and_Future_Cost_of_PV_Feb2015_web.pdf. [Accessed: 23-Nov-2017].

[11] W. A. Omran, M. Kazerani, and M.. M. A. Salama, "Investigation of Methods for Reduction of Power Fluctuations Generated From Large Grid-Connected Photovoltaic Systems,” IEEE Trans. ENERGY Convers., vol. 26, pp. 318-327, 2011.

[12] Y. An et al., "Theories and methodology of complementary hydro / photovoltaic operation : Applications to short-term scheduling," J. Renew. Sustain. Energy, vol. 7, p. http://dx.doi.org/10.1063/1.4939056, 2015.

[13] D. S. Ramos, M. T. Schilling, J. Antonio, and D. O. Rosa, "Expansão da capacidade do atendimento de ponta no Sistema Interligado Brasileiro," Revista USP, pp. 103-121, 2015.

[14] Y. Choi, “A Study on Power Generation Analysis of Floating PV System Considering Environmental Impact,” Int. J. Softw. Eng. Its Appl., vol. 8, no. 1, pp. 75-84, 2014.

[15] A. N. das Á. ANA, “Cadernos de Recursos Hídricos O TURISMO E O LAZER E SUA INTERFACE.” [Online]. Available: www.dominiopublico. gov.br/\%0Adownload/texto/an000007. [Accessed: 14-Jul-2017].

[16] M. Andrade, P. Cosenza, L. Pinguelli, and G. Lacerda, "The vulnerability of hydroelectric generation in the Northeast of Brazil : The environmental and business risks for CHESF," Renew. Sustain. Energy Rev., vol. 16, pp. 5760- 
661

662

663

664

665

666

667

668

669

670

671

672

673

674

675

676

677

678

679

680

681

682

683

684

685

5769, 2012.

[17] K. Trapani and M. R. Santafé, "A review of floating photovoltaic installations: 2007-2013," Prog. Photovolt Res. Appl., vol. 15, no. February 2013, pp. 659676, 2014.

[18] E. M. do Sacramento, P. C. M. Carvalho, J. C. de Araújo, D. B. Riffel, R. M. da C. Corrêa, and J. S. P. Neto, "Scenarios for use of floating photovoltaic plants in Brazilian reservoirs,” IET Renew. Power Gener., pp. 1019-1025, 2015.

[19] Y. Ueda, K. Kurokawa, M. Konagai, S. Takahashi, A. Terazawa, and H. Ayaki, "Five years demonstration results of floating pv systems with water spray cooling," in 27th European Photovoltaic Solar Energy Conference and Exhibition, 2012, no. March 2009, pp. 3926-3928.

[20] A. Sahu, N. Yadav, and K. Sudhakar, "Floating photovoltaic power plant: A review," Renew. Sustain. Energy Rev., vol. 66, pp. 815-824, 2016.

[21] M. de M. e E. MME, "Hidrelétrica Balbina inicia projeto com flutuadores para gerar energia solar,” 2016. [Online]. Available: http://www.mme.gov.br/web/guest/pagina-inicial/outras-noticas//asset_publisher/32 hLrOzMKwWb/content/hidreletrica-balbina-inicia-projetocom-flutuadores-para-gerar-energia-solar. [Accessed: 08-Apr-2017].

[22] S.-H. Kim, S.-J. Yoon, W. Choi, and K.-B. Choi, “Application of Floating Photovoltaic Energy Generation Systems in South Korea," Sustainability, vol. 8, no. 12, p. 1333, 2016.

[23] A. Mermoud, "PVsyst Trial v6.63.” 2017.

[24] K. Trapani, "Flexible floating thin film photovoltaic (PV) array concept for marine and lacustrine environments," Laurentian University, 2014.

[25] European Commission Joint Research Center, "Guidelines for PV Power 
Measurement in Industry,” Ispra, 2010.

[26] R. A. Messenger and J. Ventre, Photovoltaic System Engeneering, $2^{\circ}$ Edition. Taylor \& Francis e-Library, 2004.

[27] H. Bahaidarah, A. Subhan, P. Gandhidasan, and S. Rehman, "Performance evaluation of a PV (photovoltaic) module by back surface water cooling for hot climatic conditions," Energy, vol. 59, pp. 445-453, 2013.

[28] S. B. Darling, F. You, T. Veselka, and A. Velosa, "Assumptions and the levelized cost of energy for photovoltaics,” Energy Environ. Sci., vol. 4, no. 9, pp. 3133-3139, 2011.

[29] M. R. Santafé, J. B. Torregrosa-Soler, F. J. S. Romero, P. S. Ferrer-Gisbert, J. J. Ferrán-Gozálvez, and C. M. Ferrer-Gisbert, “Theoretical and experimental analysis of a floating photovoltaic cover for water irrigation reservoirs," Energy, vol. 67, pp. 246-255, 2014.

[30] R. Xu, K. Ni, Y. Hu, J. Si, H. Wen, and D. Yu, “Analysis of the optimum tilt angle for a soiled PV panel,” Energy Convers. Manag., vol. 148, pp. 100-109, 2017.

[31] A. A. Hegazy, "Effect of dust accumulation on solar transmittance through glass covers of plate-type collectors," Renew. Energy, vol. 22, pp. 525-540, 2001.

[32] Andre Mermoud, "In sheds arrangement, which power can I install on a given area ?," 2017. [Online]. Available: http://forum.pvsyst.com/viewtopic.php?f=20\&t=1994\&p=5389\&hilit=Ground+C overage+Ratio\#p5389. [Accessed: 26-Jul-2017].

[33] M. R. Santafé, "Diseño de un sistema de cubierta flotante fotovoltaica para balsas de riego," Universidade Politécnica de Valencia, 2011.

[34] S. Barkaszi and C. O’Brien, "Wind Load Calculations for PV Arrays." Solar 
American Board for Codes and Standards Report iii, p. 24, 2010.

[35] Associação Brasileira de Normas Técnicas, "NBR 6123 - Forças devidas ao vento em edificações.” ABNT, Rio de Janeiro, p. 66, 1988.

[36] C. Ferrer-Gisbert, J. J. Ferrán-Gozálvez, M. R. Santafé, P. Ferrer-Gisbert, F. J. Sánchez-Romero, and J. B. Torregrosa-Soler, “A new photovoltaic floating cover system for water reservoirs," Renew. Energy, vol. 60, pp. 63-70, 2013.

[37] C. et Terre, "Hydrelio® Components." [Online]. Available: http://www.ciel-etterre.net/hydrelio-technology/. [Accessed: 22-Oct-2017].

[38] Isigenere Renovables, "Floating System for Photovoltaic Installations Isifloating.” p. 2.

[39] W. Fang, Q. Huang, S. Huang, J. Yang, E. Meng, and Y. Li, “Optimal sizing of utility-scale photovoltaic power generation complementarily operating with hydropower : A case study of the world 's largest hydrophotovoltaic plant," Energy Convers. Manag., vol. 136, pp. 161-172, 2017.

[40] Z. Glasnovic, K. Margeta, and V. Omerbegovic, “Artificial Water Inflow Created by Solar Energy for Continuous Green Energy Production," Water Resour. Manag., vol. 27, pp. 2303-2323, 2013.

[41] Eric Hau, Wind Turbines, $2^{\circ}$ edition. Krailling: Springer, 2006.

[42] C. de C. de E. E. CCEE, "InfoMercado Individual 2014,” 2015. [Online]. Available: https://www.ccee.org.br/portal/faces/acesso_rapido_header_publico_nao_logado/ biblioteca_virtual?_afrLoop=234927870073880\#\%40\%3F_afrLoop\%3D234927 870073880\%26_adf.ctrl-state\%3D8dejbt4 mo_54. [Accessed: 31-Mar-2017].

[43] C. de C. de E. E. CCEE, “InfoMercado Individual 2015,” 2016. [Online]. Available: 
https://www.ccee.org.br/portal/faces/acesso_rapido_header_publico_nao_logado/ biblioteca_virtual?_afrLoop=234927870073880\#\%40\%3F_afrLoop\%3D234927 870073880\%26_adf.ctrl-state\%3D8dejbt4 mo_54.

[44] C. de C. de E. E. CCEE, "InfoMercado Individual 2016,” 2017. [Online]. Available:

https://www.ccee.org.br/portal/faces/acesso_rapido_header_publico_nao_logado/ biblioteca_virtual?_afrLoop=234927870073880\#\%40\%3F_afrLoop\%3D234927 870073880\%26_adf.ctrl-state\%3D8dejbt4 mo_54.

[45] E. de pesquisas energética EPE, " $23^{\circ}$ LEILÃO DE ENERGIA NOVA A-5 Resumo Vendedor,” 2016. [Online]. Available: http://www.epe.gov.br/sitespt/publicacoes-dados-abertos/publicacoes/PublicacoesArquivos/publicacao120/Resultado_completo_site_23_len.pdf. [Accessed: 29-Nov-2017]. 
Table- 1 . Main data for the hydroelectric plants that were analyzed

\begin{tabular}{|c|c|c|c|c|}
\hline Hydroelectric Plant & Abbreviation & $\begin{array}{c}\text { Installed } \\
\text { capacity }[\mathrm{MW}]\end{array}$ & $\begin{array}{c}\text { Reservoir } \\
\text { Area } \\
{\left[\mathrm{km}^{2}\right]}\end{array}$ & $\begin{array}{c}\text { Geographic } \\
\text { coordinate } \\
{\left[{ }^{\circ}\right]}\end{array}$ \\
\hline Queimado & Queimado & 105 & 39.43 & $\begin{array}{c}-16.20,- \\
47.32\end{array}$ \\
\hline Retiro Baixo & R. Baixo & 82 & 22.58 & $\begin{array}{c}-18.87,- \\
44.77\end{array}$ \\
\hline Três Marias & T. Marias & 396 & 1090 & $\begin{array}{c}-18.21,- \\
45.27\end{array}$ \\
\hline Sobradinho & Sobradinho & 1050 & 4214 & $-9.43,-40.83$ \\
\hline Itaparica & Itaparica & 1480 & 828 & $-9.14,-38.31$ \\
\hline $\begin{array}{l}\text { Complex of Paulo } \\
\text { Afonso and Apolônio } \\
\text { Sales * }\end{array}$ & $\begin{array}{l}\text { Comp. P.A } \\
\text { and A. S }\end{array}$ & 983.5 & 125.3 & $-9.42,-38.21$ \\
\hline Xingó & Xingó & 3162 & 60 & $-9.63,-37.79$ \\
\hline
\end{tabular}

Note: * The set formed by the hydroelectric power plants of Paulo Afonso I, II, III and IV and Apolônio Sales is modeled as

a single plant by the national system operator (ONS); therefore, the data provided are the generation set. 
Tab. 2. LCOE parameters

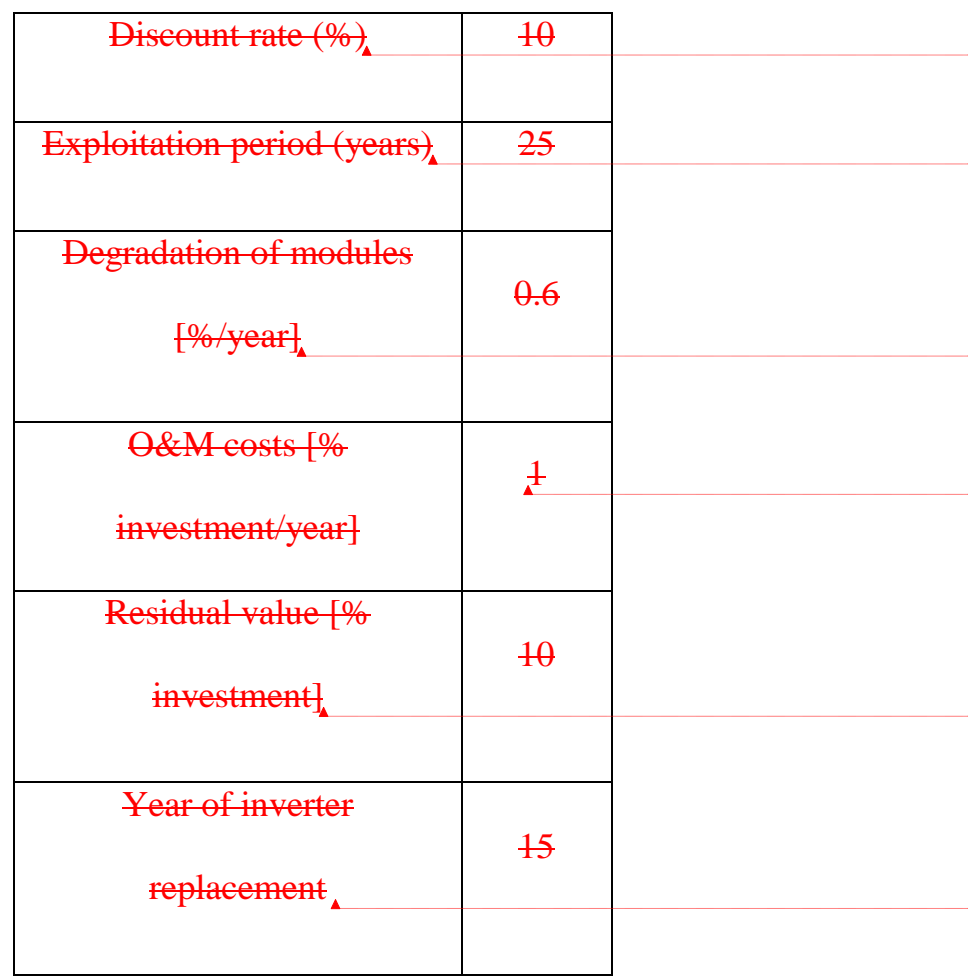

Formatted: Font: English (United States)

Formatted: Font: English (United States)

Formatted: Font: English (United States)

Formatted: Font: English (United States)

Formatted: English (United States)

Formatted: Font: English (United States)

Formatted: Font: English (United States)

Formatted: English (United States)

Table- -23 . Costs of a floating PV plant according to the tilt angle.

\begin{tabular}{|c|c|c|c|c|}
\hline $\boldsymbol{\alpha}\left[^{\circ}\right]$ & PV equipment & Floating & Anchoring & Total \\
& costs & platform costs & system costs & Costs (R\$/MW) \\
\hline 0 & $\mathrm{R} \$ 2,656,773.79$ & $\mathrm{R} \$ 920,000.00$ & $\mathrm{R} \$ 147,200.00$ & $\mathrm{R} \$ 3,723,973.79$ \\
\hline 5 & $\mathrm{R} \$ 2,656,773.79$ & $\mathrm{R} \$ 1,361,600.00$ & $\mathrm{R} \$ 239,200.00$ & $\mathrm{R} \$ 4,257,573.79$ \\
\hline 10 & $\mathrm{R} \$ 2,656,773.79$ & $\mathrm{R} \$ 1,472,000.00$ & $\mathrm{R} \$ 294,400.00$ & $\mathrm{R} \$ 4,423,173.79$ \\
\hline 15 & $\mathrm{R} \$ 2,656,773.79$ & $\mathrm{R} \$ 1,729,600.00$ & $\mathrm{R} \$ 368,000.00$ & $\mathrm{R} \$ 4,754,373.79$ \\
\hline 20 & $\mathrm{R} \$ 2,656,773.79$ & $\mathrm{R} \$ 1,950,400.00$ & $\mathrm{R} \$ 441,600.00$ & $\mathrm{R} \$ 5,048,773.79$ \\
\hline 25 & $\mathrm{R} \$ 2,656,773.79$ & $\mathrm{R} \$ 2,318,400.00$ & $\mathrm{R} \$ 515,200.00$ & $\mathrm{R} \$ 5,490,373.79$ \\
\hline 30 & $\mathrm{R} \$ 2,656,773.79$ & $\mathrm{R} \$ 2,760,000.00$ & $\mathrm{R} \$ 625,600.00$ & $\mathrm{R} \$ 6,042,373.79$ \\
\hline
\end{tabular}


Table $-\underline{3} 4$. Albedo of the water as a function of solar height $\gamma$

\begin{tabular}{|c|c|}
\hline Sun height $\boldsymbol{\gamma}\left[^{\circ}\right]$ & Albedo $\boldsymbol{\rho}$ \\
\hline 10 & 0.128 \\
\hline 20 & 0.103 \\
\hline 30 & 0.084 \\
\hline$>40$ & 0.070 \\
\hline
\end{tabular}

Table- 54 . Summary of the simulations for different topologies in the hydroelectric Três Marias Power Plant

\begin{tabular}{|c|c|c|c|c|c|c|c|c|}
\hline $\boldsymbol{\alpha}\left[{ }^{\circ}\right]$ & $\boldsymbol{\theta}$ & $\mathbf{U F}$ & $\begin{array}{c}\mathbf{P}_{\text {man }} \\
{\left[{ }^{\circ}\right]}\end{array}$ & $\begin{array}{c}\mathbf{P}_{\text {sha }} \\
{[\mathbf{m}]}\end{array}$ & $\mathbf{P}[\mathbf{m}]$ & $\mathbf{A}_{\text {flo }}\left[\mathbf{m}^{2}\right]$ & $\begin{array}{c}\mathbf{E}_{\text {nor }} \\
{\left[\mathbf{k W}_{\mathbf{p}} / \mathbf{m}^{2}\right]}\end{array}$ & $\begin{array}{c}{[\mathbf{M W h}} \\
\left.\mathbf{y e a r} / \mathbf{M W}_{\mathbf{p}}\right]\end{array}$ \\
\hline 0 & 0 & 0.66 & 1.49 & - & 1.49 & 9860.6 & 0.101414 & 1651.1 \\
\hline 1 & 2 & 0.66 & 1.49 & - & 1.49 & 9860.6 & 0.101414 & 1659.6 \\
\hline 2 & 3.9 & 0.66 & 1.49 & - & 1.49 & 9860.6 & 0.101414 & 1667.7 \\
\hline 3 & 5.9 & 0.66 & 1.49 & - & 1.49 & 9860.6 & 0.101414 & 1675.2 \\
\hline 4 & 7.8 & 0.66 & 1.49 & - & 1.49 & 9860.6 & 0.101414 & 1682.3 \\
\hline 5 & 9.7 & 0.66 & 1.49 & - & 1.49 & 9860.6 & 0.101414 & 1688.7 \\
\hline 10 & 19.2 & 0.67 & 1.47 & - & 1.47 & 9713.4 & 0.102950 & 1711.7 \\
\hline 15 & 27.0 & 0.68 & 1.46 & 1.37 & 1.46 & 9570.6 & 0.104487 & 1719.9 \\
\hline 20 & 31.8 & 0.67 & 1.43 & 1.48 & 1.48 & 9713.4 & 0.102950 & 1715.7 \\
\hline 25 & 31.9 & 0.63 & 1.40 & 1.57 & 1.57 & 10330.2 & 0.096804 & 1704.5 \\
\hline 30 & 32 & 0.60 & 1.36 & 1.65 & 1.65 & 10846.7 & 0.092194 & 1683.1 \\
\hline
\end{tabular}


Table- $6 \underline{5}$. Peak powers and occupied areas of floating PV plants.

\begin{tabular}{|c|c|c|c|c|c|}
\hline Hydroelectric & Type & $\begin{array}{l}\text { Power } \\
{\left[\mathbf{M W}_{\mathbf{p}}\right]}\end{array}$ & $\begin{array}{c}\text { PV area } \\
{\left[\mathbf{k m}^{2}\right]}\end{array}$ & $\begin{array}{l}\text { Reservoir } \\
\text { area }\left[\mathbf{k m}^{2}\right]\end{array}$ & $\begin{array}{c}\text { Surface } \\
\text { occupation } \\
{[\%]}\end{array}$ \\
\hline Queimado & $\begin{array}{l}\text { Storage } \\
\text { reservoir }\end{array}$ & 105 & 1.04 & 39.43 & $2.63 \%$ \\
\hline Retiro Baixo & $\begin{array}{l}\text { Storage } \\
\text { reservoir }\end{array}$ & 82 & 0.81 & 22.58 & $3.58 \%$ \\
\hline Três Marias & $\begin{array}{l}\text { Storage } \\
\text { reservoir }\end{array}$ & 396 & 3.90 & 1090 & $0.36 \%$ \\
\hline Sobradinho & $\begin{array}{l}\text { Storage } \\
\text { reservoir }\end{array}$ & 1050 & 10.35 & 4214 & $0.25 \%$ \\
\hline Itaparica & $\begin{array}{l}\text { Storage } \\
\text { reservoir }\end{array}$ & 1479.6 & 14.59 & 828 & $1.76 \%$ \\
\hline Paulo Afonso & Run-of-the- & & & & $12.33 \%$ \\
\hline I, II, III & river & $60 \underline{1417}$ & $0.59 \underline{13.97}$ & 4.8 & $\underline{291.09 \%}$ \\
\hline $\begin{array}{c}\text { Paulo Afonso } \\
\text { IV }\end{array}$ & $\begin{array}{c}\text { Run-of-the- } \\
\text { river }\end{array}$ & $\begin{array}{r}410 \\
2462 \\
\end{array}$ & $\begin{array}{r}4.04 \\
\underline{24.28} \\
\end{array}$ & 12.9 & $\begin{array}{l}31.34 \% \\
188.19 \% \\
\end{array}$ \\
\hline $\begin{array}{c}\text { Apolônio } \\
\text { Sales }\end{array}$ & $\begin{array}{l}\text { Run-of-the- } \\
\text { river }\end{array}$ & $100 \underline{400}$ & 0.993 .94 & 98 & $1.01 \% 4.02 \%$ \\
\hline Xingó & $\begin{array}{c}\text { Run-of-the- } \\
\text { river }\end{array}$ & 3162 & 28.98 & 60 & $48.31 \%$ \\
\hline
\end{tabular}

Formatted: Portuguese (Brazil) 
Table2. Costs of a floating PV plant according to the tilt angle.

\begin{tabular}{|c|c|c|c|c|}
\hline $\boldsymbol{\alpha}\left[{ }^{\circ}\right]$ & PV equipment & Floating & Anchoring & Total \\
& costs & platform costs & system costs & Costs (R\$/MW) \\
\hline 0 & $\mathrm{R} \$ 2,656,773.79$ & $\mathrm{R} \$ 920,000.00$ & $\mathrm{R} \$ 147,200.00$ & $\mathrm{R} \$ 3,723,973.79$ \\
\hline 5 & $\mathrm{R} \$ 2,656,773.79$ & $\mathrm{R} \$ 1,361,600.00$ & $\mathrm{R} \$ 239,200.00$ & $\mathrm{R} \$ 4,257,573.79$ \\
\hline 10 & $\mathrm{R} \$ 2,656,773.79$ & $\mathrm{R} \$ 1,472,000.00$ & $\mathrm{R} \$ 294,400.00$ & $\mathrm{R} \$ 4,423,173.79$ \\
\hline 15 & $\mathrm{R} \$ 2,656,773.79$ & $\mathrm{R} \$ 1,729,600.00$ & $\mathrm{R} \$ 368,000.00$ & $\mathrm{R} \$ 4,754,373.79$ \\
\hline 20 & $\mathrm{R} \$ 2,656,773.79$ & $\mathrm{R} \$ 1,950,400.00$ & $\mathrm{R} \$ 441,600.00$ & $\mathrm{R} \$ 5,048,773.79$ \\
\hline 25 & $\mathrm{R} \$ 2,656,773.79$ & $\mathrm{R} \$ 2,318,400.00$ & $\mathrm{R} \$ 515,200.00$ & $\mathrm{R} \$ 5,490,373.79$ \\
\hline 30 & $\mathrm{R} \$ 2,656,773.79$ & $\mathrm{R} \$ 2,760,000.00$ & $\mathrm{R} \$ 625,600.00$ & $\mathrm{R} \$ 6,042,373.79$ \\
\hline
\end{tabular}

Table3. Albedo of the water as a function of solar height $\gamma$

\begin{tabular}{|c|c|}
\hline Sun height $\gamma\left[{ }^{[}{ }^{\mathbf{}}\right]$ & Albedo $\boldsymbol{\rho}$ \\
\hline 10 & 0.128 \\
\hline 20 & 0.103 \\
\hline 30 & 0.084 \\
\hline$>40$ & 0.070 \\
\hline
\end{tabular}

Table 4. Summary of the simulations for different topologies in the hydroelectric Três Marias Power Plant

\begin{tabular}{|c|c|c|c|c|c|c|c|c|}
\hline$\alpha\left[^{\circ}\right]$ & $\begin{array}{c}\boldsymbol{\theta} \\
{\left[{ }^{\circ}\right]}\end{array}$ & UF & $\begin{array}{r}\mathbf{P}_{\text {man }} \\
{[\mathrm{m}]}\end{array}$ & $\begin{array}{r}\mathbf{P}_{\text {sha }} \\
{[\mathrm{m}]}\end{array}$ & $\mathbf{P}[\mathbf{m}]$ & $\mathbf{A}_{\text {flo }}\left[\mathbf{m}^{2}\right]$ & $\begin{array}{c}D_{\text {Pow }} \\
{\left[\mathbf{k} \mathbf{W}_{\mathbf{p}} / \mathbf{m}^{2}\right]}\end{array}$ & $\begin{array}{c}\mathbf{E}_{\mathbf{n o r}} \\
{[\mathrm{MWh}} \\
\text { year/MW }\end{array}$ \\
\hline
\end{tabular}


Table 4. Summary of the simulations for different topologies in the hydroelectric Três Marias Power Plant

\begin{tabular}{|c|c|c|c|c|c|c|c|c|}
\hline $\boldsymbol{\alpha}\left[{ }^{\circ}\right]$ & $\boldsymbol{\theta}$ & $\mathbf{U F}$ & $\mathbf{P}_{\text {man }}$ & $\mathbf{P}_{\text {sha }}$ & $\mathbf{P}[\mathbf{m}]$ & $\mathbf{A}_{\mathbf{f l o}}\left[\mathbf{m}^{2}\right]$ & $\begin{array}{c}\mathbf{D}_{\text {Pow }} \\
{\left[\mathbf{k W}_{\mathbf{p}} / \mathbf{m}^{2}\right]}\end{array}$ & $\begin{array}{c}\left.{ }^{\circ}\right] \\
{[\mathbf{M W h}} \\
\left.\mathbf{y e a r} / \mathbf{M W}_{\mathbf{p}}\right]\end{array}$ \\
\hline 0 & 0 & 0.66 & 1.49 & - & 1.49 & 9860.6 & 0.101414 & 1651.1 \\
\hline 1 & 2 & 0.66 & 1.49 & - & 1.49 & 9860.6 & 0.101414 & 1659.6 \\
\hline 2 & 3.9 & 0.66 & 1.49 & - & 1.49 & 9860.6 & 0.101414 & 1667.7 \\
\hline 3 & 5.9 & 0.66 & 1.49 & - & 1.49 & 9860.6 & 0.101414 & 1675.2 \\
\hline 4 & 7.8 & 0.66 & 1.49 & - & 1.49 & 9860.6 & 0.101414 & 1682.3 \\
\hline 5 & 9.7 & 0.66 & 1.49 & - & 1.49 & 9860.6 & 0.101414 & 1688.7 \\
\hline 10 & 19.2 & 0.67 & 1.47 & - & 1.47 & 9713.4 & 0.102950 & 1711.7 \\
\hline 15 & 27.0 & 0.68 & 1.46 & 1.37 & 1.46 & 9570.6 & 0.104487 & 1719.9 \\
\hline 20 & 31.8 & 0.67 & 1.43 & 1.48 & 1.48 & 9713.4 & 0.102950 & 1715.7 \\
\hline 25 & 31.9 & 0.63 & 1.40 & 1.57 & 1.57 & 10330.2 & 0.096804 & 1704.5 \\
\hline 30 & 32 & 0.60 & 1.36 & 1.65 & 1.65 & 10846.7 & 0.092194 & 1683.1 \\
\hline
\end{tabular}

Table 5. Peak powers and occupied areas of floating PV plants.

\begin{tabular}{|c|c|c|c|c|c|}
\hline Hydroelectric & Type & $\begin{array}{l}\text { Power } \\
{\left[\mathbf{M W}_{\mathbf{p}}\right]}\end{array}$ & $\begin{array}{c}\text { PV } \\
\text { area } \\
{\left[\mathrm{km}^{2}\right]}\end{array}$ & $\begin{array}{l}\text { Reservoir } \\
\text { area }\left[\mathrm{km}^{2}\right]\end{array}$ & $\begin{array}{c}\text { Surface } \\
\text { occupation } \\
{[\%]}\end{array}$ \\
\hline Queimado & $\begin{array}{l}\text { Storage } \\
\text { reservoir }\end{array}$ & 105 & 1.04 & 39.43 & $2.63 \%$ \\
\hline
\end{tabular}


Table 5. Peak powers and occupied areas of floating PV plants.

\begin{tabular}{|c|c|c|c|c|c|}
\hline Hydroelectric & Type & $\begin{array}{l}\text { Power } \\
{\left[\mathbf{M W}_{\mathbf{p}}\right]}\end{array}$ & $\begin{array}{c}\text { PV } \\
\text { area } \\
{\left[\mathrm{km}^{2}\right]}\end{array}$ & $\begin{array}{l}\text { Reservoir } \\
\text { area }\left[\mathbf{k m}^{2}\right]\end{array}$ & $\begin{array}{c}\text { Surface } \\
\text { occupation } \\
{[\%]}\end{array}$ \\
\hline Retiro Baixo & $\begin{array}{l}\text { Storage } \\
\text { reservoir }\end{array}$ & 82 & 0.81 & 22.58 & $3.58 \%$ \\
\hline Três Marias & $\begin{array}{l}\text { Storage } \\
\text { reservoir }\end{array}$ & 396 & 3.90 & 1090 & $0.36 \%$ \\
\hline Sobradinho & $\begin{array}{l}\text { Storage } \\
\text { reservoir }\end{array}$ & 1050 & 10.35 & 4214 & $0.25 \%$ \\
\hline Itaparica & $\begin{array}{l}\text { Storage } \\
\text { reservoir }\end{array}$ & 1479.6 & 14.59 & 828 & $1.76 \%$ \\
\hline $\begin{array}{c}\text { Paulo Afonso } \\
\text { I, II, III }\end{array}$ & $\begin{array}{l}\text { Run-of-the- } \\
\text { river }\end{array}$ & 1417 & 13.97 & 4.8 & $291.09 \%$ \\
\hline $\begin{array}{c}\text { Paulo Afonso } \\
\text { IV }\end{array}$ & $\begin{array}{l}\text { Run-of-the- } \\
\text { river }\end{array}$ & 2462 & 24.28 & 12.9 & $188.19 \%$ \\
\hline $\begin{array}{c}\text { Apolônio } \\
\text { Sales }\end{array}$ & $\begin{array}{c}\text { Run-of-the- } \\
\text { river }\end{array}$ & 400 & 3.94 & 98 & $4.02 \%$ \\
\hline Xingó & $\begin{array}{l}\text { Run-of-the- } \\
\text { river }\end{array}$ & 3162 & 28.98 & 60 & $48.31 \%$ \\
\hline
\end{tabular}




\section{Figure(s)}

Click here to download high resolution image

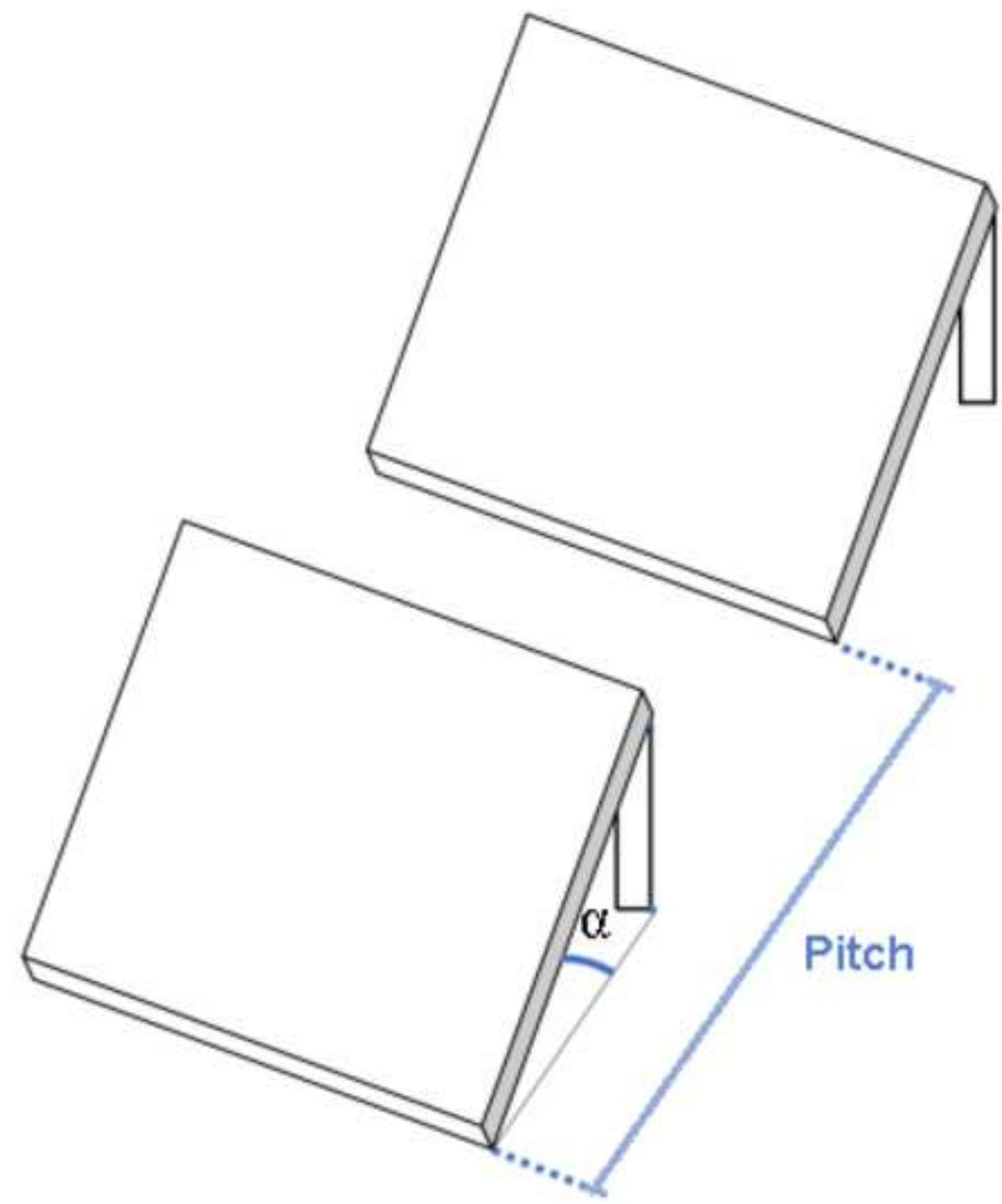


Click here to download high resolution image

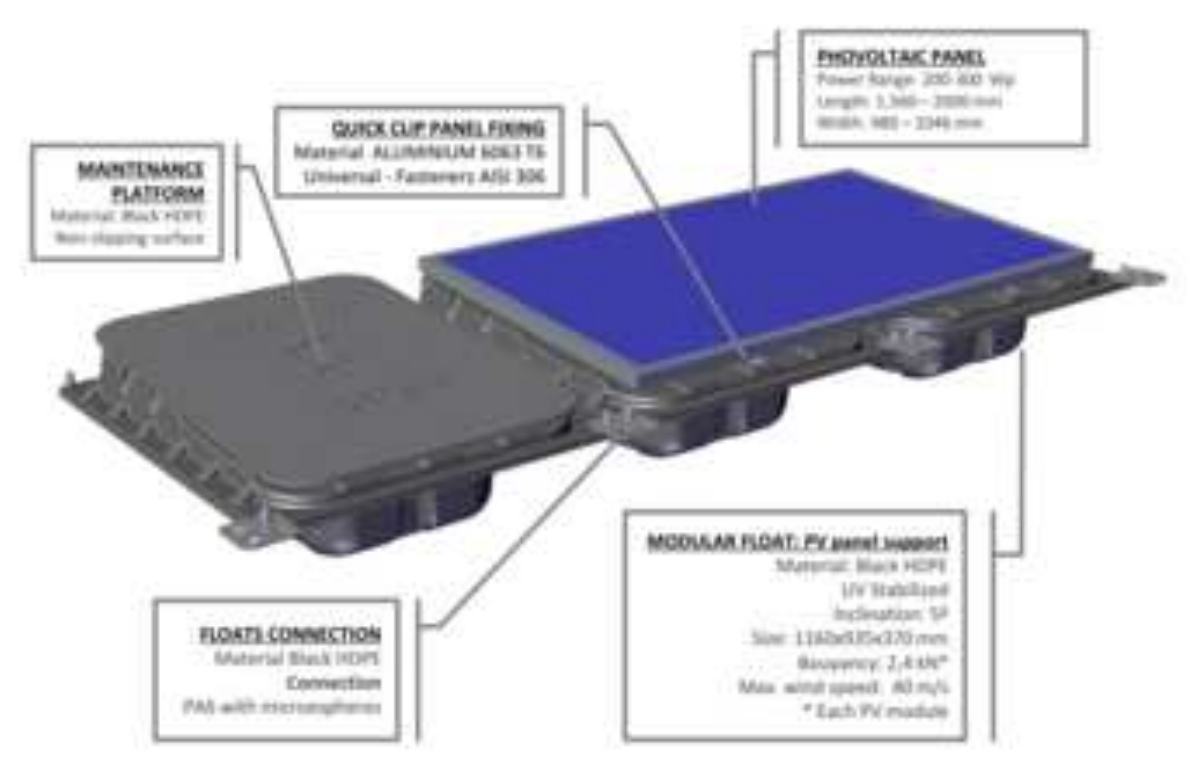

a) Isifloating

) Isifloating

(2)

-

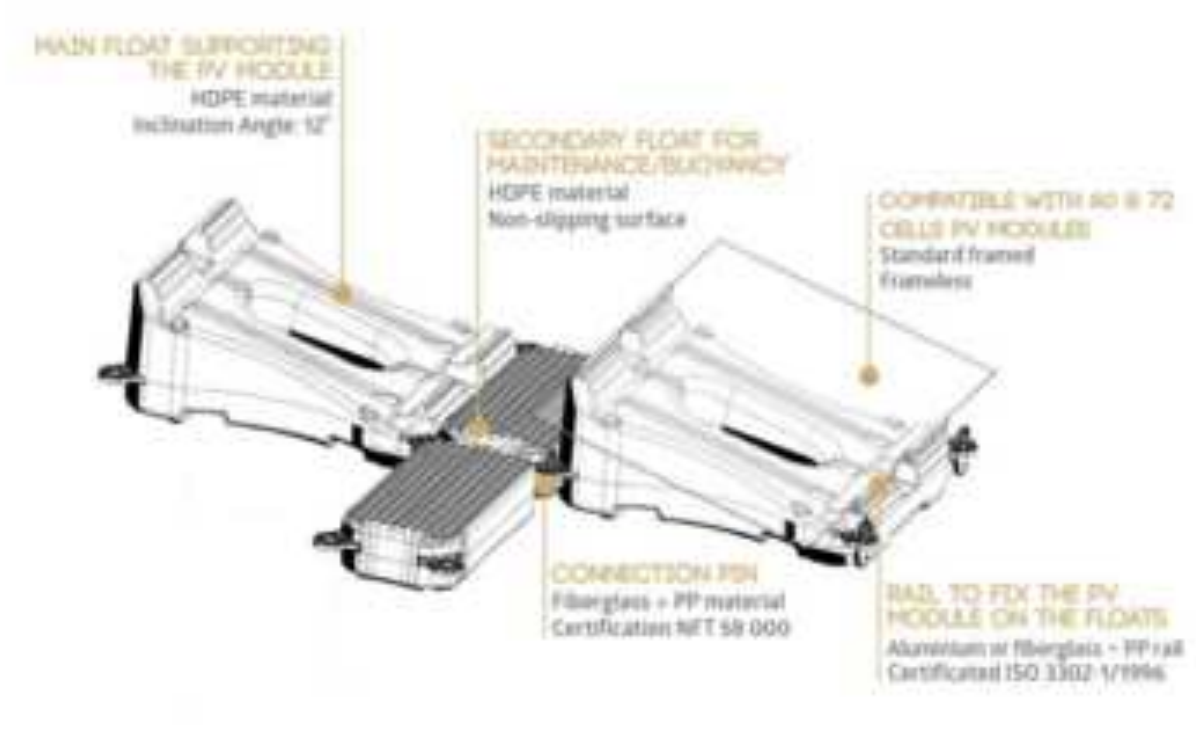
b) Hydrelio

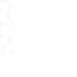




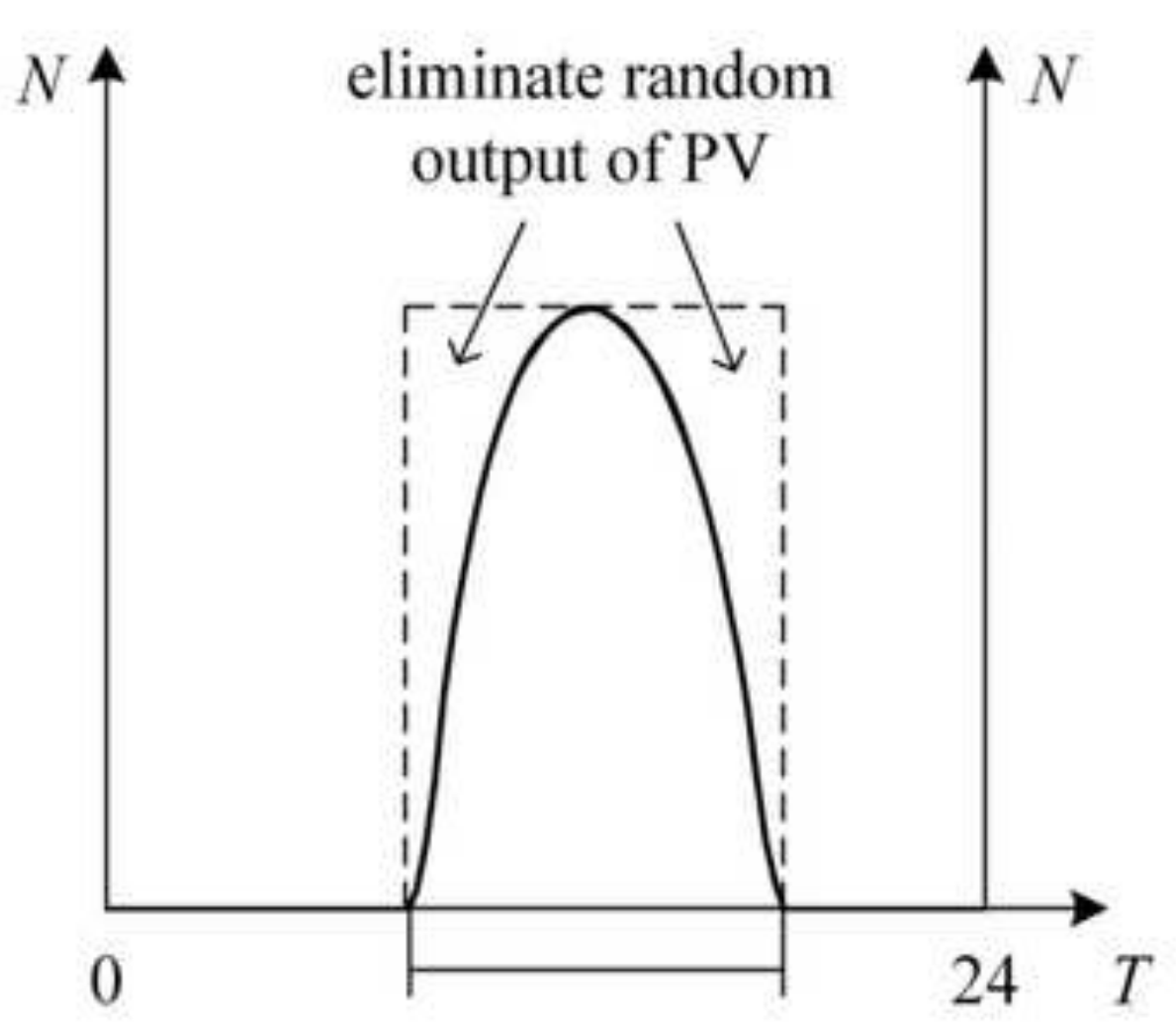

(a)

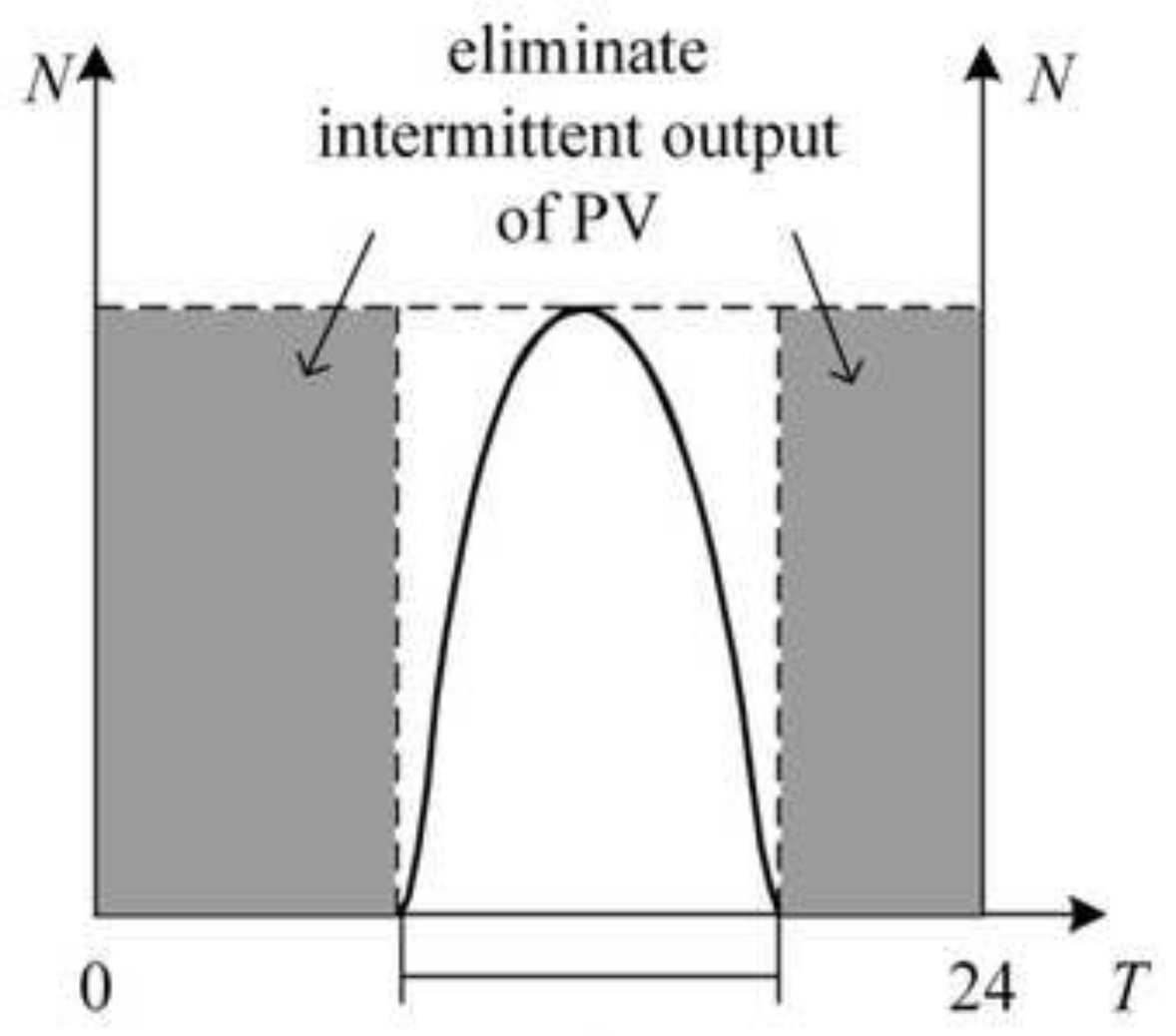

(b) 
Click here to download high resolution image

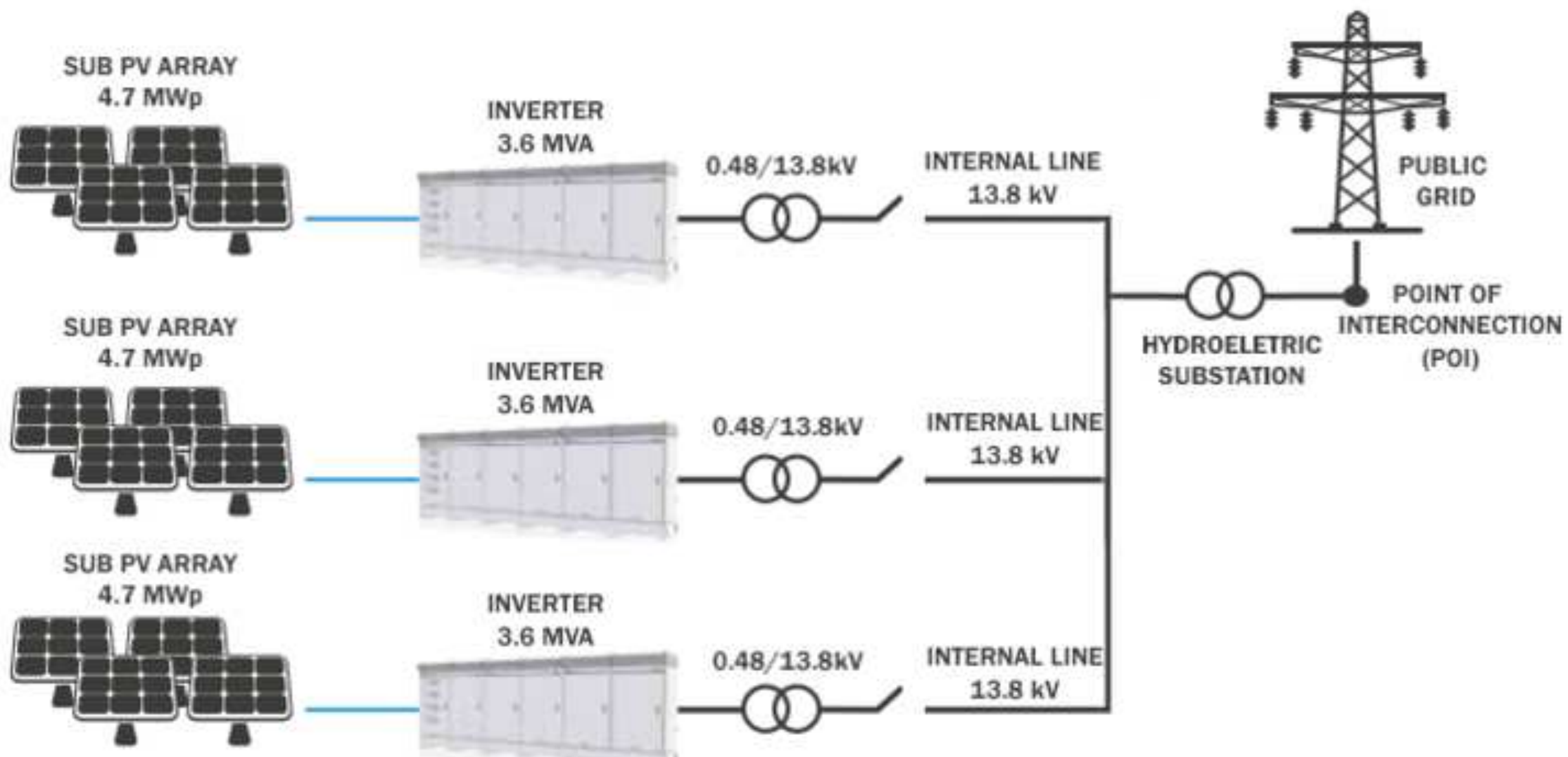

\section{NVERTER}

T3.8 KV

INVERTER

3.6 MVA

YDROELETRIC CONNECTION

NVERTER

3.6 MVA 


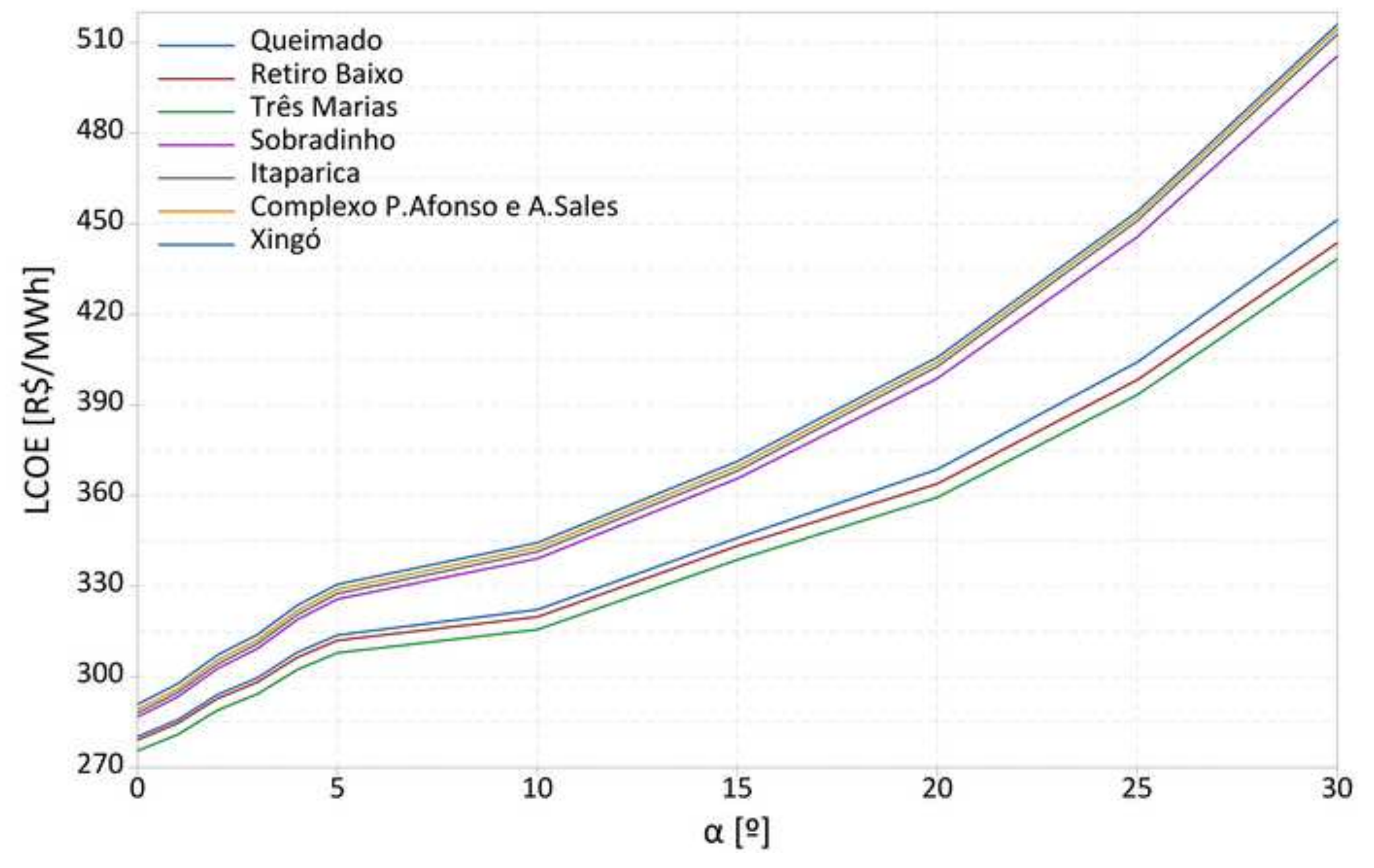


Click here to download high resolution image

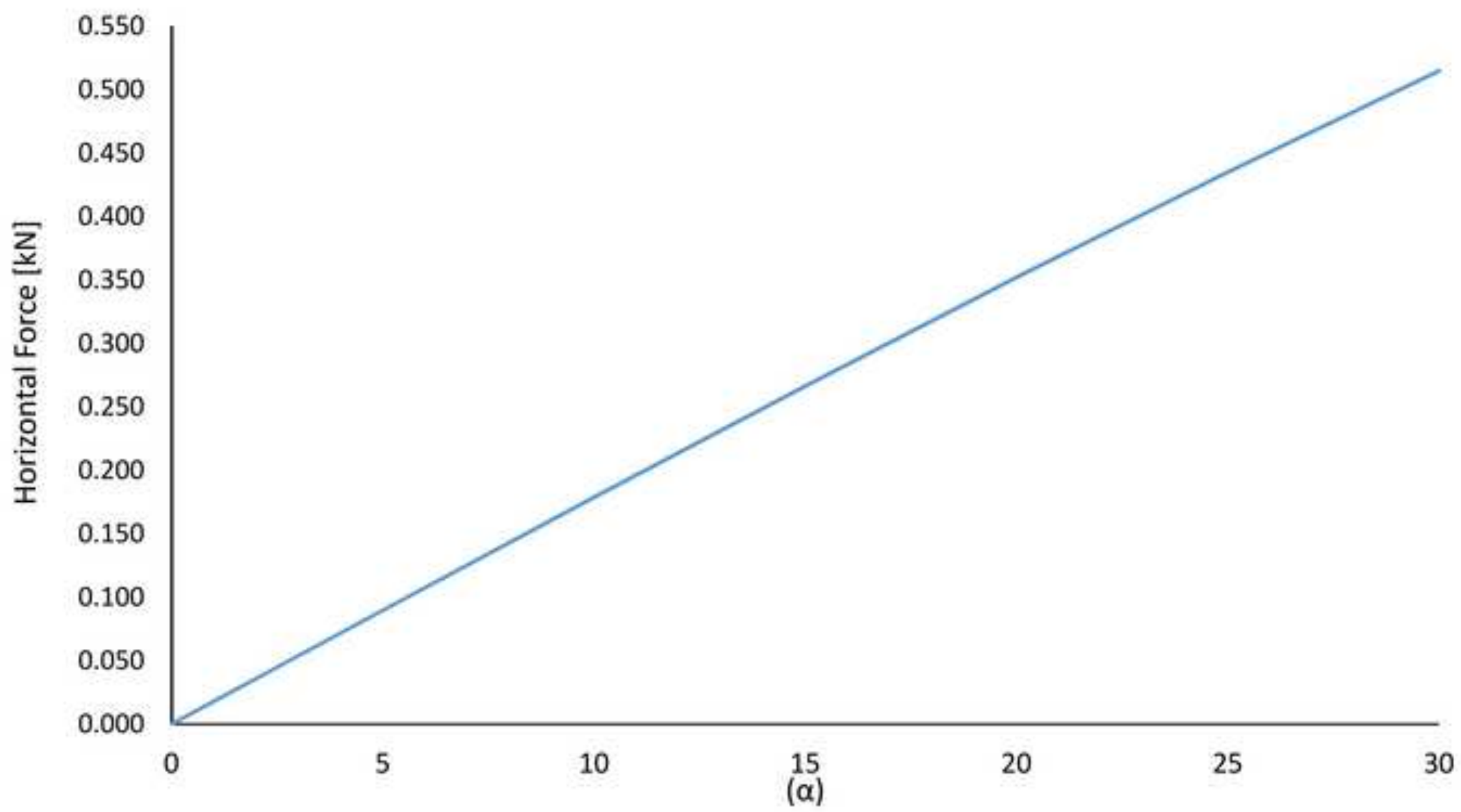




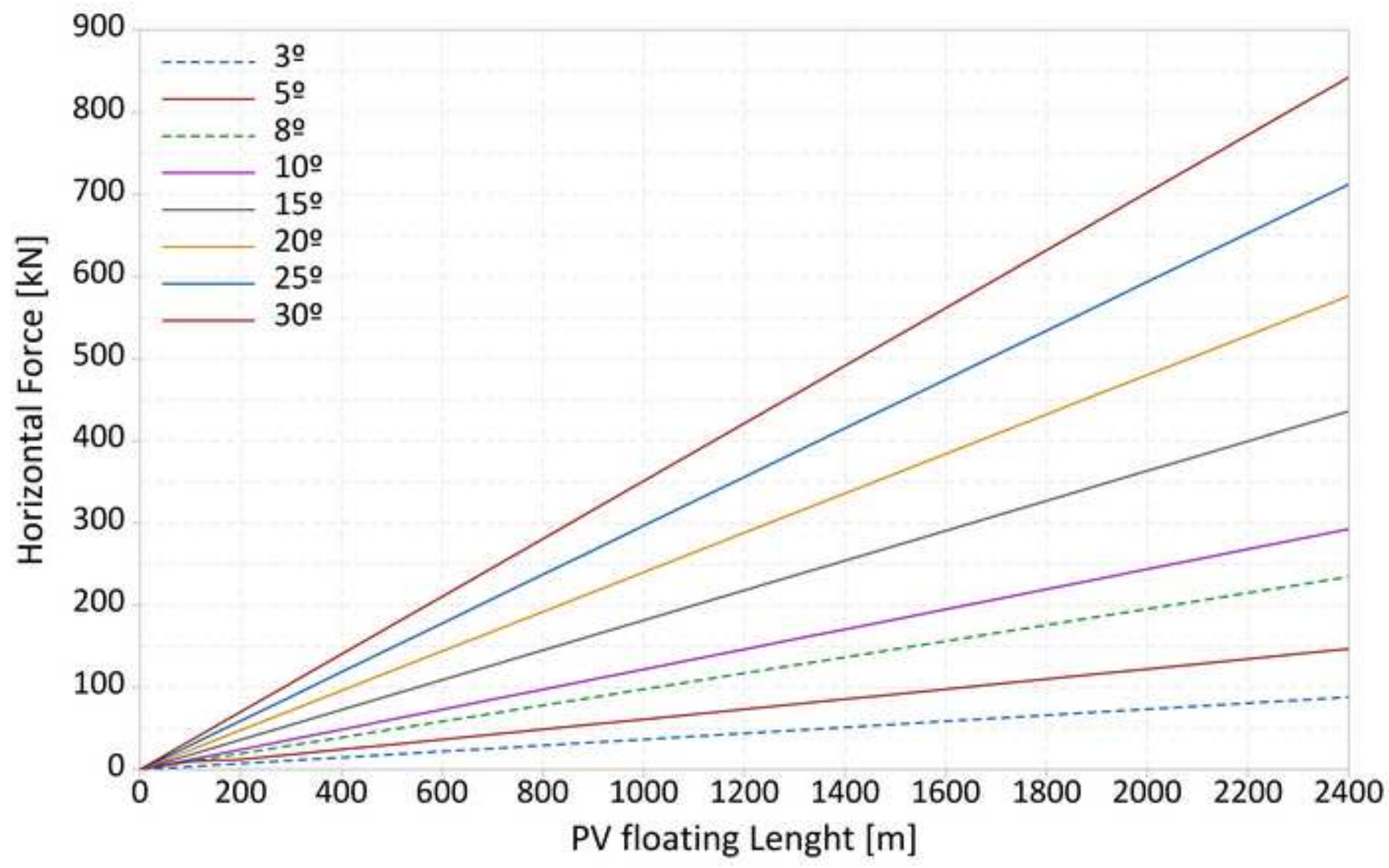


Click here to download high resolution image

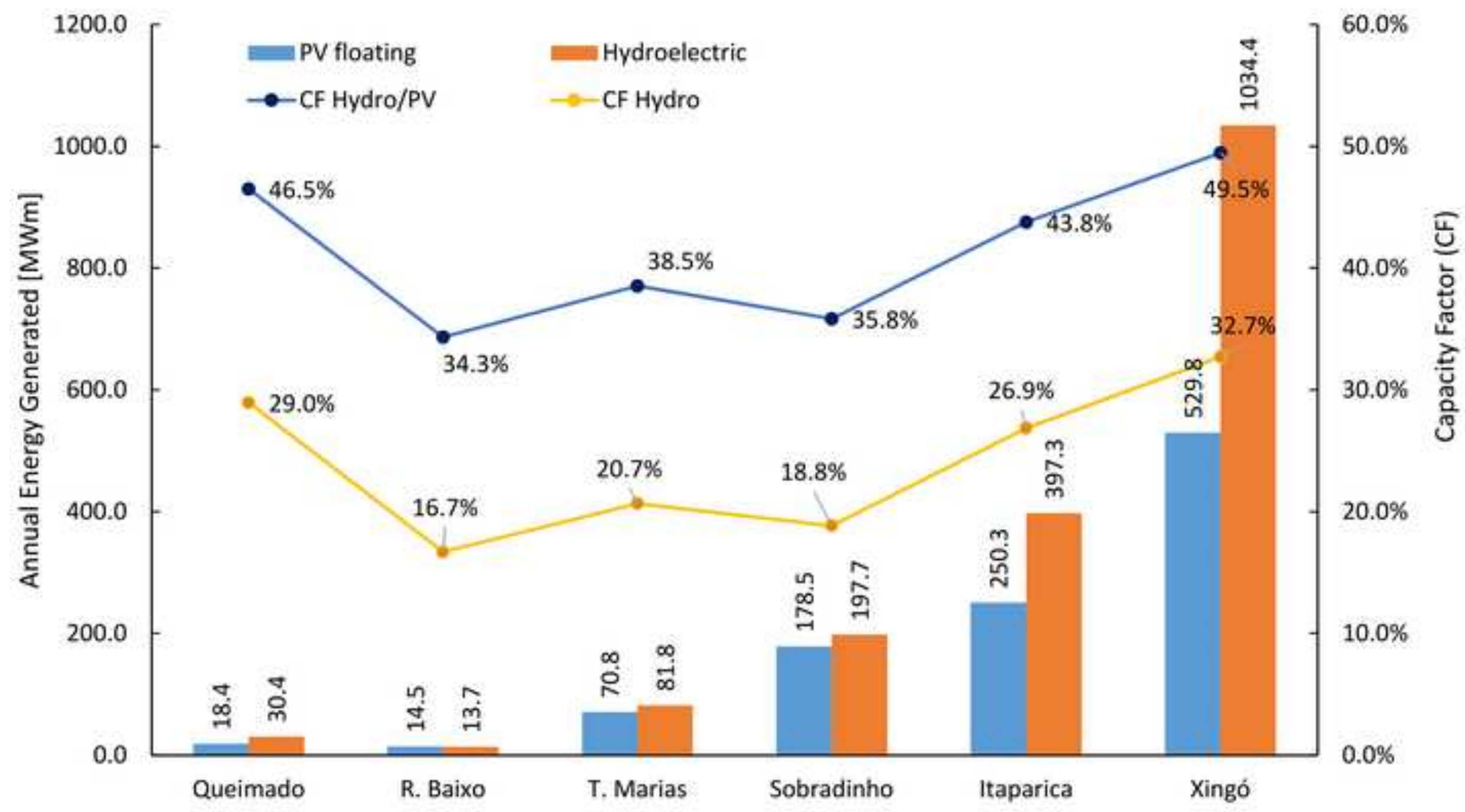



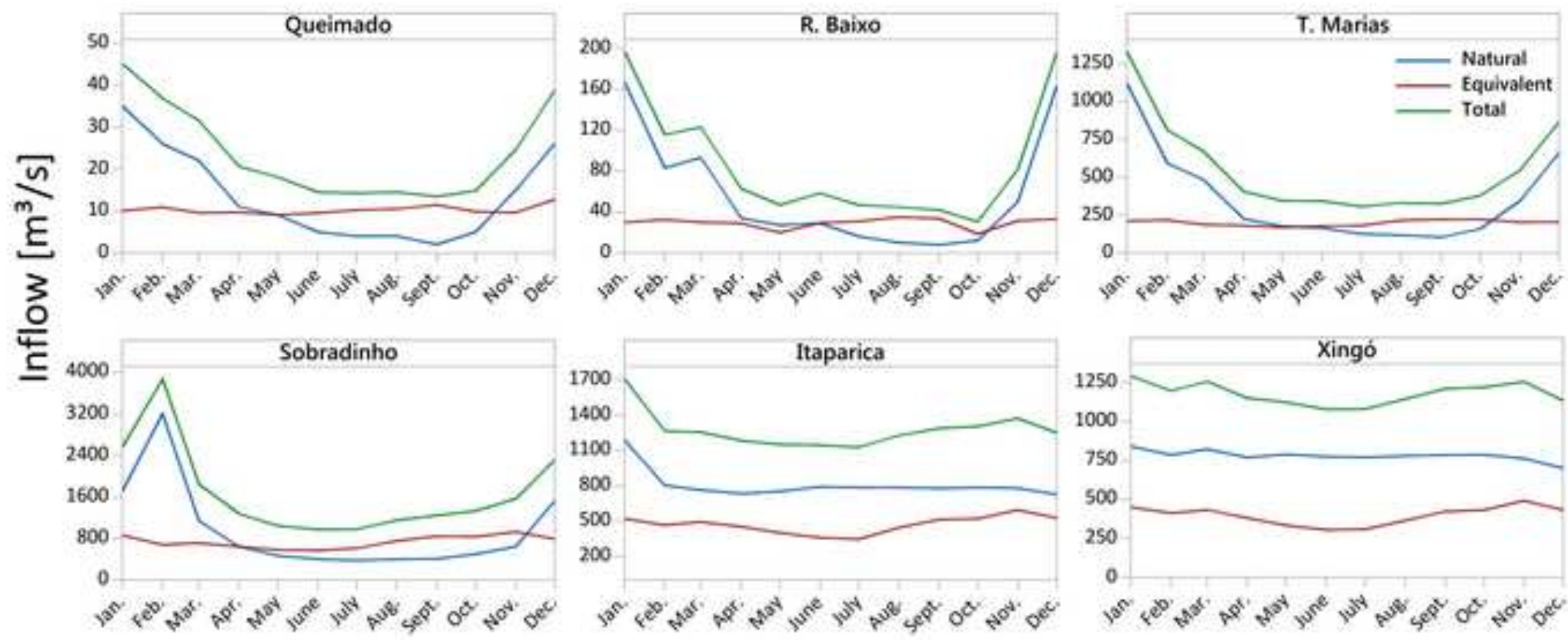


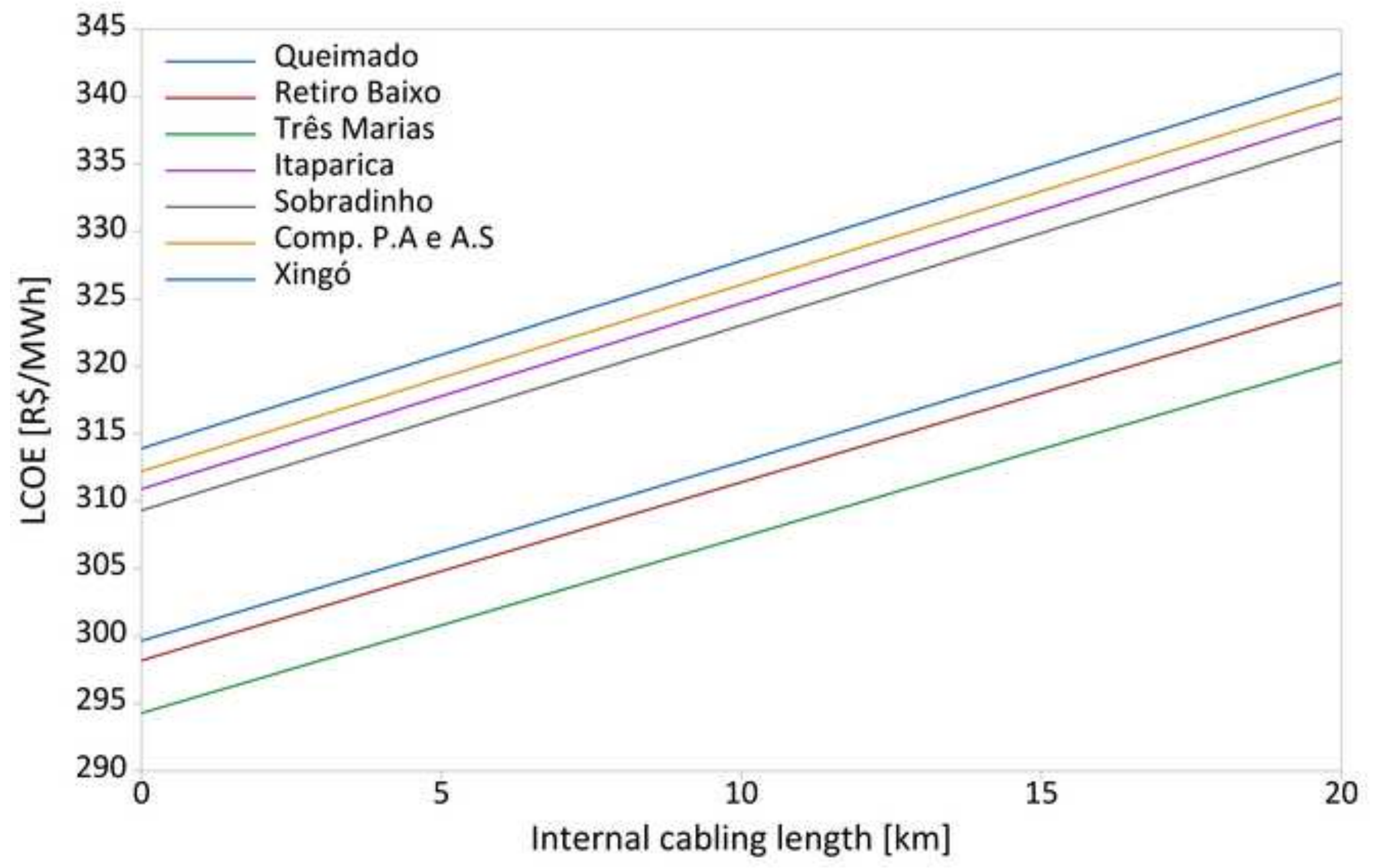

